\title{
Contributing Factors to Excess Weight Gain During Pregnancy Among Low Income Women in Utah
}

Tianna Noelle Watson

Brigham Young University - Provo

Follow this and additional works at: https://scholarsarchive.byu.edu/etd

Part of the Food Science Commons, and the Nutrition Commons

\section{BYU ScholarsArchive Citation}

Watson, Tianna Noelle, "Contributing Factors to Excess Weight Gain During Pregnancy Among Low Income Women in Utah" (2010). Theses and Dissertations. 2531.

https://scholarsarchive.byu.edu/etd/2531

This Thesis is brought to you for free and open access by BYU ScholarsArchive. It has been accepted for inclusion in Theses and Dissertations by an authorized administrator of BYU ScholarsArchive. For more information, please contact scholarsarchive@byu.edu, ellen_amatangelo@byu.edu. 
Contributing factors to excess weight gain during pregnancy

among low-income women in Utah

Tianna Smith Watson

A thesis submitted to the faculty of

Brigham Young University

in partial fulfillment of the requirements for the degree of

Master of Science

Rickelle Richards, Chair

Tory Parker

Rosemary Thackeray

Department of Nutrition, Dietetics, and Food Science

Brigham Young University

August 2010

Copyright (C) 2010 Tianna Smith Watson

All Rights Reserved 


\begin{abstract}
Contributing factors to excess weight gain during pregnancy

among low-income women in Utah
\end{abstract}

Tianna Smith Watson

Department of Nutrition, Dietetics, and Food Science

Master of Science

Objective: To evaluate factors influencing excessive weight gain during pregnancy and changes in eating patterns from the pre-pregnancy period among low-income women $(<185 \%$ poverty level).

Design, Setting, \& Participants: Low-income women who were at least 7-months pregnant and gained excess weight $(n=14)$ or normal weight $(n=15)$ were interviewed. Questions pertained to previous nutritional knowledge, eating patterns, and sources for obtaining nutrition information.

Outcome Measures and Analysis: Transcripts were coded independently by two researchers, with any differences reconciled. Common themes were discussed and tallied to determine the most commonly re-occurring topics reported in the interviews.

Results: Most of the excess weight gainers (EWG) and recommended weight gainers (RWG) had a heightened awareness of their eating patterns and became more concerned about the impact their diet had on their fetus' health during (vs. before) pregnancy. EWG and RWG received limited nutrition- and weight-related advice from their doctors, and relied on alternate sources of information, such as pregnancy books and online websites. The most noted difference between the groups was that RWG reported more accurate nutrition knowledge than EWG.

Conclusions and Implications: Nutrition knowledge indirectly affects the amount of weight women gain during pregnancy. EWG and RWG received minimal nutritional and weightrelated advice from doctors during or after pregnancy. This suggests the need for increased counseling efforts by doctors in providing appropriate nutrition and weight-related advice to their patients or providing outside referrals to registered dietitians.

Keywords: pregnancy, excess weight gain, nutrition knowledge, nutrition advice, physicians, health perception 


\section{ACKNOWLEDGEMENTS}

\section{"Go confidently in the direction of your dreams! \\ Live the life you've imagined."}

-Thoreau

I am filled with gratitude for the many people who have supported me these last two years in graduate school. I would first like to thank my wonderful advisor, Dr. Rickelle Richards who has really been a mentor to me at BYU. Her constant support and encouragement has kept me going and she has been a major contributor to my success. I am grateful that I had the opportunity to work with her. She is such an intelligent woman and a great person to be around. I will never forget the many laughs we shared together when reading over our interview transcripts! She has taught me how to be an effective interviewer, which is one of the most important skills I will take with me and use throughout my entire career. I am so grateful that together we were able to come up with a wonderful research project that I have learned so much from and that I have thoroughly enjoyed.

I also want to say thank you to my committee members, Drs. Tory Parker and Rosemary Thackeray. They have also contributed to making my project stronger and I am thankful that they were willing to be a part of it. Nick Rainey is another great contributor to this project and I am so grateful for the many transcripts and data entries he did for me. He was truly a blessing!

I am also very grateful for the amazing women I had the opportunity to meet and interview for this project. Their willingness to share their personal experiences allowed me to create a great project that I hope will allow health professionals to gain more insight into the health perceptions and behaviors of low-income pregnant women. I would also like to thank my peers who I shared these last two years with at BYU. Brita Ball, Jessica Zetterquist, Janice 
Darko, and Mary Curtis are all smart, fun women who have all been a great support to me and I am grateful that I was able to experience this journey with them.

I would also like to thank my family who has always told me to make education a priority and to never give up on my dreams. My parents have set a wonderful example for me and I hope to do the same for my own children someday. I would also like to thank my husband who has always encouraged me to further my education and who has always supported me in everything I do. Thank you to everyone who has contributed to my success. I will be forever thankful for your advice, encouragement, and support. Lastly, I am so grateful for the gospel in my life and for my Heavenly Father. My personal prayers and His guidance have really gotten me through this program and I can’t imagine how difficult it would have been to do it alone. I am grateful for the strength He has given me to strive to be my best. 


\section{Brigham Young University}

\section{SIGNATURE PAGE}

of a thesis submitted by

Tianna Smith Watson

The thesis of Tianna Watson is acceptable in its final form including (1) its format, citations, and bibliographical style are consistent and acceptable and fulfill university and department style requirements; (2) its illustrative materials including figures, tables, and charts are in place; and (3) the final manuscript is satisfactory and ready for submission.

Date

Date

Date

Date

Date
Rickelle Richards, Chair

Tory Parker

Rosemary Thackeray

Susan Fullmer, Graduate Coordinator

Rodney J. Brown, Dean of College of Life Sciences 


\section{TABLE OF CONTENTS}

Title page $\quad$ i

$\begin{array}{lll}\text { Abstract } & \text { ii }\end{array}$

Acknowledgements $\quad$ iii

Signature page $\quad$ V

Table of contents $\quad$ vi

List of tables $\quad$ viii

Manuscript (prepared for submission to the Amer J Obstet Gynocol)

$\begin{array}{lr}\text { Abstract } & 1 \\ \text { Introduction } & 2 \\ \text { Materials and methods } & 3 \\ \text { Results } & 5 \\ \text { Discussion } & 10 \\ \text { References } & 17 \\ \text { Tables } & 21\end{array}$

$\begin{array}{lr}\text { Appendices } & 29\end{array}$

$\begin{array}{ll}\text { Appendix A: Literature review } & 30\end{array}$

Excess Weight Gain $\quad 30$

$\begin{array}{ll}\text { Nutrition Knowledge and Education } & 31\end{array}$

Low-Income Population Risks 33

Body Image Postpartum 35

$\begin{array}{ll}\text { Theoretical Model } & 36\end{array}$

$\begin{array}{ll}\text { Potential Implications } & 36\end{array}$

Appendix B: Methods 38 
$\begin{array}{ll}\text { Eligibility Requirements } & 38\end{array}$

$\begin{array}{ll}\text { Exclusion Criteria } & 38\end{array}$

Time 1: During Pregnancy 39

$\begin{array}{ll}\text { Recruitment Methods } & 39\end{array}$

$\begin{array}{ll}\text { Interview Questions during Pregnancy } & 40\end{array}$

Time 2: Postpartum Period 41

$\begin{array}{ll}\text { Data Analysis } & 41\end{array}$

Appendix C: Recruitment flyer $\quad 42$

Appendix D: Telephone screening for research study eligibility 43

Appendix E: Baby Your Baby weight gain charts 46

Appendix F: Statement of informed consent 50

Appendix G: Interview questions during pregnancy 52

Appendix H: Interview questions after pregnancy 54

Appendix I: Demographics questionnaire during pregnancy 56

Appendix J: USDA’s Food Security Scale 63

Appendix K: Demographics questionnaire after pregnancy 66 


\section{LIST OF TABLES}

Table I: Interview guide during and after pregnancy

Table II: Demographic characteristics of interview participants $(n=28)$

Table III: Selected quotes to illustrate main themes and subthemes 


\title{
ABSTRACT \\ Contributing Factors to Excess Weight Gain during Pregnancy among low-income Women in Utah
}

\author{
Tianna Smith Watson, MS \\ Rickelle Richards, PhD, MPH, RD
}

Objective To evaluate factors influencing excessive weight gain during pregnancy and changes in eating patterns from the pre-pregnancy period among low-income women $(<185 \%$ poverty level).

Design, Setting, \& Participants Low-income women who were at least 7-months pregnant and gained excess weight $(n=14)$ or normal weight $(n=15)$ were interviewed. Questions pertained to previous nutritional knowledge, eating patterns, and sources for obtaining nutrition information.

Outcome Measures and Analysis Transcripts were coded independently by two researchers, with any differences reconciled. Common themes were discussed and tallied to determine the most commonly re-occurring topics reported in the interviews.

Results Most of the excess weight gainers (EWG) and normal weight gainers (NWG) had a heightened awareness of their eating patterns and became more concerned about the impact their diet had on their fetus' health during (vs. before) pregnancy. EWG and NWG received limited nutrition- and weight-related advice from their doctors, and relied on alternate sources of information, such as pregnancy books and online websites. The most noted difference between the groups was that NWG reported more accurate nutrition knowledge than EWG.

Conclusions and Implications Nutrition knowledge indirectly affects the amount of weight women gain during pregnancy. EWG and NWG received minimal nutritional and weightrelated advice from doctors during or after pregnancy. This suggests the need for increased counseling efforts by doctors in providing appropriate nutrition and weight-related advice to their patients or providing outside referrals to registered dietitians.

This study was internally funded by Brigham Young University.

Key words: pregnancy, excess weight gain, nutrition knowledge 


\section{INTRODUCTION}

Recently, in the state of Utah, the Pregnancy Risk Assessment Monitoring System (PRAMS) program reported that close to $50 \%$ of women gained an excessive amount of weight during pregnancy, suggesting this is a significant public health issue in the state (Utah Department of Health, 2008). Prior research has suggested pre-pregnancy obesity and excessive weight gain during pregnancy as risk factors for macrosomia, cesarean delivery, and postpartum weight retention, which if sustained long-term could lead to adverse health consequences associated with adult obesity, such as diabetes and heart disease (Abrams et al, 2000; Brawarsky et al, 2005; Fowles and Walker, 2006).

Olson (2005) evaluated factors influencing excessive weight gain during pregnancy and found that limited discussion of weight gain by health care providers and living in poverty (< $185 \%$ of the poverty line) were significant risk factors. According to the Institute of Medicine, women should be receiving nutrition counseling before, during, and after pregnancy in order to improve the quality of their diets and their overall health (Institute of Medicine, 1990). One program that involves nutrition education during and after pregnancy is the Special Supplemental Nutrition Program for Women, Infants, and Children (WIC), which aims to educate low-income pregnant women on healthy dietary habits and appropriate weight gain during pregnancy. Furthermore, WIC provides vouchers to improve access and intake of healthy foods as a means to enhance pregnancy outcomes. A policy change in 2009 allows WIC participants to receive fresh fruits and vegetables and whole grain products (United States Department of Agriculture, [no date]). However, despite government food assistance efforts, low-income women continue to gain excessive amounts of weight during pregnancy and retain the weight in the postpartum 
period (Utah Department of Health, 2008; Guelinckx et al, 2008; Crowell, 1995; Walker et al, 2005).

Low-income women are faced with intensive stress due to limited finances and access to health care, which may lead to health disparities over time (George et al, 2005b; Chang et al, 2008; Sudor et al, 2006). Drewnowski and Darmon (2005) showed that high-caloric, low nutrient dense foods tend to be more cost efficient than healthier food items, which can be appealing for those with limited economic resources. Although prior research has indicated changes in eating patterns during pregnancy and risk factors for postpartum weight retention, limited research has used a theoretical approach to evaluate factors influencing eating patterns and health perceptions among low-income women in the perinatal period. Thus this study used the social cognitive theory to qualitatively examine eating patterns, weight gain concerns, and perceptions about health among low-income pregnant women in Utah and how this changes in the postpartum period.

\section{MATERIALS AND METHODS}

We conducted in-person interviews with the same women $(n=29)$ at two time periods: during pregnancy (February 2009 - November 2009) and two to four months postpartum (June 2009 - March 2010). Participants were low-income women who were currently participating in the WIC Program or were income-eligible for the WIC Program, who were at least 7 months pregnant, and resided in Utah County. Exclusion criteria included women $<18$ years of age, women who were not fluent in English, and women gaining an inadequate amount of weight during pregnancy, based on their current week of gestation. During the telephone screening process for the study enrollment, eligible women were classified into one of two groups: “recommended weight gainer (RWG)" or "excessive weight gainer (EWG).” Criteria for 
evaluating weight gain included women's pre-pregnancy body mass index (BMI), weeks of gestation, and amount of weight gained at their current weeks of gestation. After obtaining the women's pre-pregnancy BMI, the Baby Your Baby's Pregnancy Weight Gain chart, which is adapted from the Institute of Medicine's weight gain recommendations, was used to assess weight gain at their current weeks of gestation (Institute of Medicine, 2010; Baby Your Baby, 2010). According to the Institute of Medicine's recommendations (2010), women should gain within the following ranges for their respective BMI categories: underweight (BMI < 18.5), 28 40 pounds; normal weight (BMI 18.5-24.9), 25 - 35 pounds; overweight (BMI 25.0 - 29.9), 15 25 pounds; and obese (BMI > 30), 11-20 pounds. If a woman fell within the recommended range, she was classified as a RWG. If she was above the recommended weight gain range, she was classified as a EWG. Fifteen participants were EWG and fourteen were RWG. These terms were only used by the researchers to classify participants into their appropriate categories and were not disclosed to participants.

The during pregnancy interviews lasted about 60 minutes and postpartum interviews lasted about 45 minutes. Interviews were audio-taped and transcribed verbatim for data analysis. An interview guide was used to ensure that similar questions were asked to each participant (Table I). The Social Cognitive Theory, which postulates a dynamic, triadic relationship between three constructs - the environment, behavior, and personal factors, served as the underlying theoretical framework for developing interview questions (Bandura, 1971; Bandura, 1977). Interview topics included changes in eating and exercise habits, perceptions about the WIC program, nutrition-related advice received or sought after, and attitudes towards health during and after pregnancy. Before the interviews, participants signed an informed consent form and completed a sociodemographics questionnaire, which included questions about dietary and 
exercise habits during and after pregnancy. Due to digital recording errors two interviews were summarized by the interviewer rather than transcribed verbatim. 24-hour recalls were also conducted using 3-dimensional food models to increase accuracy and measured height and weight to the nearest $0.1 \mathrm{~cm}$ and $0.1 \mathrm{~kg}$, respectively. This study was approved by the Institutional Review Board at Brigham Young University.

Two researchers evaluated interview transcripts independently using open-coding methods and any discrepancies in coding between the researchers were reconciled prior to further analysis. Transcripts were evaluated both collectively and separately. The main ideas from the transcripts were discussed, summarized, and tallied to determine the most commonly reoccurring codes and how these varied between the two groups (RWG vs. EWG). Common themes and subthemes emerged based on this evaluation. Descriptive statistics were used to evaluate sociodemographic and anthropometric variables. Student t-tests and chi-square statistics were used to compare subjects' responses between RWG and EWG groups. One EWG participant was excluded from the sociodemographic data because she was pregnant with twins.

\section{RESULTS}

Table II presents sociodemographic characteristics of participants during pregnancy and from the postpartum follow-up. Most participants had an annual household income below \$39,999 and 55\% and 57\% participated in WIC during pregnancy and in the postpartum period, respectively. All participants had at least some college education and 86\% were Caucasian. All participants also received prenatal care and no participants had diabetes or hypertension before or during pregnancy (data not shown). EWG gained $41.3 \pm 14$ pounds and the RWG gained $31.2 \pm 6.3$ pounds on average. 
Interviews revealed four main themes that were commonly discussed during this study:

(1) health awareness and use of WIC vouchers during pregnancy; (2) nutrition advice during pregnancy; (3) nutrition awareness and behaviors between EWG and RWG; and (4) health perceptions and attitudes after pregnancy. Each main theme had specific subthemes that further explained the main themes: (1) awareness of dietary intake and baby's health and WIC vouchers; (2) health professionals; media resources; and family and friends; (3) eating patterns; and nutrition and weight gain knowledge; and family traditions; and (4) weight loss; health attitudes and baby's health; and nutrition advice from physicians. Table III provides selected quotes by theme and subtheme.

\section{Theme 1: Health Awareness and Use of WIC Vouchers during Pregnancy}

Awareness of Dietary Intake and Baby's Health. Most participants were more concerned with their health and became more aware of their eating patterns during pregnancy compared to before pregnancy. The main reason for this heightened awareness, as expressed by most participants, was the desire to be healthy for the sake of their fetus' growth and development. WIC Vouchers. Most participants who received WIC benefits agreed that they liked the new vouchers, which included fresh produce, whole grain products, and more low-fat dairy options. Furthermore, they felt that the new WIC vouchers met their dietary needs and that the fresh produce vouchers, in particular, benefited their health. One participant explained her feelings about the new produce vouchers by saying: "I love them because now we can get more fresh fruits...fresh fruits can be expensive, especially in the wintertime, and so now we can have a lot more which is great.” (RWG) Another participant had similar thoughts about the new produce vouchers and said: "It has been nice for us to have the fresh fruits and vegetables and I think its 
made it so we can have more of them in our house more often..we're making sure that they're integrated a lot more so that's been nice for us.” (EWG)

\section{Theme 2: Nutrition Advice during Pregnancy}

Most participants reported receiving limited nutrition- and weight-related advice from health professionals, including physicians and WIC nutritionists. Alternatively, they relied on other sources of information, such as pregnancy books, online websites, and social networks, including family and friends.

Health Professionals. Most participants did not receive nutrition- or weight gain-related advice from their primary care physicians. A few EWG reported that they felt their weight gain was above recommended levels, but because their health providers did not address it, they figured it was not significant to warrant concern or wished that their physicians had approached them about it. However, a few participants mentioned that their physicians or midwives provided them with some nutritional advice during pregnancy, such as drink more water, eat a balanced diet, and take omega-3 fatty acid and prenatal supplements.

For those participants using WIC, most women did not like the educational aspect of the program and mentioned that they received little to no nutrition advice during pregnancy. One participant explained that she would like WIC employees to offer the rationale behind specific nutrition recommendations: “They talk about the importance of drinking [water] but they don’t really talk about why..and so I think if women understood what happens to their bodies more during pregnancy I think women would be more inclined to take care of themselves.” (RWG) Another participant expressed her thoughts about WIC by saying: "I would like the nutrition classes to actually be nutrition classes instead of how to use WIC [vouchers]..if their goal is to educate it would be nice to have that extra resource.” (EWG) 
Media Resources. Most participants used the internet as a main source for obtaining nutrition information. A few participants mentioned that they do a Google search to find answers to their nutrition questions or they refer to babycenter.com. Many women were interested in finding information regarding food safety, what micronutrients they need to incorporate more into their diets, and caloric needs during pregnancy. To determine which sources provided valid advice, participants commonly checked a few websites to evaluate consistency between information; if more than one site reported it, some felt this offered evidence of credibility. Many participants also referred to pregnancy-related books and magazines for nutrition-related information.

Family and Friends. Social networks, such as family and friends, emerged as a common source for nutrition information among many participants. Both groups stated that friends and family provided them with nutrition-related advice, particularly that they should eat what their body craves and they should eat whatever they want because they are pregnant.

\section{Theme 3: Nutrition Awareness and Behaviors between EWG and RWG}

Clear differences became evident between the two groups' eating patterns and nutrition knowledge prior to becoming pregnant and during pregnancy. Differences also emerged between the two groups' health-related family traditions.

Eating patterns. The interviews revealed that most participants in the RWG group reported eating a healthy diet before and during pregnancy compared to those in the EWG group who mainly reported eating whatever they wanted during pregnancy. In addition, more EWG participants, compared to RWG, stated that their cravings during pregnancy were a major influence on their dietary intake.

Nutrition and weight gain Knowledge. Most EWG reported inaccurate nutrition knowledge during pregnancy, whereas most RWG demonstrated accurate nutrition knowledge during 
pregnancy. For example, one participant stated, “Omega-3’s and DHA are in fish oils and they [contribute to] brain development and eye development for your baby.” (RWG) Another participant said, “I’ve gained weight, but I’m really not that big compared to what I could be I guess. I haven’t gained a ton of weight and I'm on a good track for weight gain I think.” (EWG)

Family Traditions. Many RWG mentioned that health was emphasized in their home growing up, compared to only a couple EWG whom reported nutrition was an important focus in their family. One participant mentioned: "Even though I think that healthy vegetables and healthy food are more expensive I think there's a balance because a lot of times the cheapest things aren't the best for you and someday you'll pay for it with like maybe more health care. That's kind of the mentality I was raised with. You pay for quality now.” (RWG) In contrast, another participant stated: "I have a big family and not only do we eat a lot but you have to eat it fast or else it will be gone. Like my family eats everyone else’s food too you know so there's a lot of pressure to eat a lot of it and eat it fast...the competition that I felt growing up [makes me] eat a ton with [my husband].” (EWG)

\section{Theme 4: Health Perceptions and Attitudes after Pregnancy}

Weight loss. Differences emerged between the groups when asked about their feelings regarding weight loss. EWG more commonly expressed concerns about losing the weight associated with their pregnancies compared to the RWG. Even though only a few RWG claimed that they were worried about losing weight, many participants in both groups stated that they would like to exercise more to lose weight rather than focus on changing their dietary habits. One EWG stated, “It's not going to be as easy as I thought it was [to lose weight]...so I am a lot more motivated to just be healthier exercise wise. I’ve always been fairly healthy eating wise, besides the occasional jug of ice cream, but yeah, exercise has always been kind of my weak point.” One 
RWG also mentioned, “I’ve realized that with every pregnancy you won't just lose your weight by nursing and so if I exercise that will be helpful.”

Health Attitudes and Baby's Health. Similarly to during pregnancy, many participants expressed their desire to continue to be healthy for their baby's health. Many women felt that because they were breastfeeding their dietary habits were still directly affecting their baby’s growth and development. A few women also stated that having a baby has motivated them to want to live a healthy lifestyle.

Nutrition Advice from Physicians. Both groups commonly stated that they received no nutrition or weight loss advice after pregnancy, and only a few participants mentioned that their physicians provided nutrition or weight loss advice. A few participants mentioned that their physicians are more concerned with their baby's health and growth rather than their own health. One EWG stated, “They’re all more concerned with [my baby].”

\section{DISCUSSION}

The Social Cognitive Theory can be used to explain how health awareness, educationseeking behaviors, and advice during and after pregnancy affects dietary intake. Women in our study made attempts to improve their eating patterns because of personal beliefs about having a healthy baby and because of the advice they sought after and received from their friends and family. Eating patterns and personal health-related perceptions and attitudes were also influenced by the environment, particularly lack of nutrition advice by health care professionals, the internet and social networks.

The findings from the interviews suggest that women have a heightened awareness of their dietary patterns during pregnancy for the health and development of their fetuses, and after pregnancy, for the health of their growing infants. Many women in our study expressed more 
concern about making healthy dietary choices during pregnancy compared to before pregnancy because they felt some sense of responsibility for their growing infant. Although some women knew eating healthy was important at all times in their lives, they were not as concerned about healthy eating for themselves, but once they became pregnant, recognized the need to make positive changes for the health of their infant. Another study, conducted among Dutch women, similarly found that pregnant mothers have an increased awareness about their dietary intake for the sake of their babies' health and development (Szwajcer et al, 2005). However, in our study differences in health perceptions between the pregnancy weight gain groups and from the pregnancy to postpartum period became evident. Specifically, EWG were more likely to perceive that they could eat whatever they wanted during pregnancy, whereas many of the RWG focused on maintaining a healthy diet during their pregnancies. This perception may offer one explanation for the excessive weight gain among some pregnant women. Furthermore, many RWG reported that the importance of health was emphasized in their homes growing up, which influenced their dietary behaviors as adults. Prior research has suggested that the emphasis of proper nutrition in infancy and childhood may have long-term positive effects on health as an adult (Lanigan \& Singhal, 2009).

In the postpartum follow-up, women in our study continued to feel a sense of responsibility for their growing infants, and many felt that they need to eat healthy to have a healthy baby. Because most of our participants were breastfeeding in the postpartum period, they saw this as a way of directly affecting the health of their babies. However, it became apparent that women from our study focused on exercise to aid in weight loss, with few mentioning any adjustments in dietary intake. To promote the most effective means for postpartum weight loss, women should be educated by health care professionals on combining 
both healthy dietary practices and aerobic exercise to increase the probability of returning to their prepregnancy weight or to achieve a healthy weight (Weaver, 2008; Amorim, 2008).

Because women from our study were more concerned about their baby's health during pregnancy, they sought out nutrition-related education. Women from our study indicated that many health care professionals did not provide them with adequate nutrition education during or after pregnancy. As a result, they were relying on alternative sources such as social networks, searching the internet, and books and magazines, which may be providing them with inaccurate information (Fox \& Fallows, 2003). As of December 2002, about 80\% of adult Americans relied on the internet for nutrition education and resources. Because there is a lack of editorial control over what can be posted on websites, many internet-users often receive inaccurate nutrition information (Fox \& Fallows, 2003). The Google search engine and babycenter.com were commonly used among participants in our study, which may provide nutrition-related information from non-nutrition or health-related professionals. Babycenter.com provides answers from gynecologists and some dietitians to commonly asked questions during pregnancy, which can provide them with accurate health-related information; however, women can also receive advice from other mothers, which may be an inaccurate source for education.

Women in our study perceived website credibility by checking multiple sources to determine if the same information was repeated. However, this may be an inappropriate measure for determining credibility. Because some women in our study may have perceived inaccurate nutrition information online as true, this may contribute to misconceptions of nutrition during and after pregnancy. Lack of nutritional knowledge has been associated with excess weight gain during pregnancy, which was also indicated in our study (Nuss et al, 2007). RWG reported more accurate nutrition information compared to EWG, which suggests that if more women received 
accurate nutrition information from credentialed health professionals during and after pregnancy, excess weight gain during pregnancy and weight retention postpartum rates may decrease (Olson, 2005).

Pregnancy has been termed a "teachable moment" due to the emotional and physical adjustments that occur, making it an appropriate time to provide nutrition education and promote health behavioral change (Phelan, 2010). Healthy People 2020 has an objective to "increase the proportion of patients whose doctor recommends personalized health information resources to help them manage their health” (Healthy People 2020, 2010). By doing so, this may contribute to women reaching another Healthy People 2020 objective to "increase the proportion of mothers who achieve a recommended weight gain during their pregnancies.” In addition, Michelle Obama's White House task force against childhood obesity recommends that health care professionals should provide women with information about the importance of maintaining a healthy weight before pregnancy and should promote meeting the Institute of Medicine's weight gain recommendations during pregnancy (Task Force on Childhood Obesity, 2010). To reach the Healthy People 2020 and the Obesity Task Force goals, this suggests health care professionals should be engaging in better nutrition education efforts during and after pregnancy. However, Hiddink et al (1995) found that physicians believe that patients do not care about changing their dietary habits, which is one important barrier for providing patients with nutritionrelated education. Although this may be true for patients who are not pregnant, our study indicates that low-income pregnant women do care about changing their dietary habits during pregnancy and their exercise habits postpartum. Many participants in our study expressed that they would like to receive nutrition education from their physicians. Although some physicians asked our participants if they had any questions, many women stated that they didn’t even know 
what to ask. In addition, some EWG believed their physicians would talk to them about their weight gain if it was too high or too low. Because many EWG were not informed about their excessive weight gain during pregnancy, they felt it was nothing to be concerned about.

Some physicians may not be providing nutrition information to patients because of time constraints and a lack of nutrition knowledge, which suggests other methods of education may be appropriate (Hiddink et al, 1995). For example, physicians can refer patients to a dietitian who has been trained to provide accurate nutrition education to individuals. However, currently Medicaid does not typically offer reimbursement for such services. Because recent government policies are aiming to promote healthier practices during pregnancy through nutrition education, further policy changes should include such services that would likely decrease the high prevalence of excess weight gain during pregnancy and postpartum weight retention. Physicians could also suggest accurate health professional-related websites to learn from, such as United States Department of Agriculture's MyPyramid.gov for pregnant and breastfeeding women or the American Dietetic Association's website, eatright.org. Patients using WIC can also be referred to wichealth.org for accurate information. Further research is needed to determine the underlying barriers for physicians providing weight gain advice, especially among those patients gaining excessive amounts of weight during pregnancy, and the feasibility of referring patients to alternative sources, such as dietitians and credible online resources.

Many women in our study also reported that they did not receive nutrition-related information from the nutritionists and dietitians at WIC clinics. A few women felt that WIC addressed issues such as breastfeeding and using the WIC vouchers, but they would have liked to have received more nutrition-related advice. In addition, some women felt that WIC nutritionists and dietitians told them what they should be eating during pregnancy, but they didn’t explain the 
importance behind these beneficial changes. A recent study found that coordinated nutrition education, which emphasizes the importance of consuming fruits and vegetables, whole grains, and low-fat milk products, increased WIC participants' consumption of fruit, whole grains, and low-fat milk, suggesting that nutrition education from WIC nutritionists and dietitians may aid in dietary behavioral change (Ritchie et al, 2010). In addition, WIC recently launched wichealth.org which may provide more proper nutrition information to WIC participants through online education modules; however, further research is needed to determine the effectiveness of this new website in improving clients’ nutrition knowledge and actual health behaviors.

Although many participants from our study were dissatisfied with the educational aspect of the WIC program, the new changes made with the WIC vouchers received positive comments by the majority of participants using the program. Many women stated that they particularly liked the new produce vouchers and it helped to increase their consumption of fresh fruits and vegetables, which may help them obtain greater variety of nutrient-dense foods; however, it was suggested that the voucher money be split up throughout the month to prevent produce from perishing and to allow intake consistency over the course of an entire month.

There were a few limitations of our study. Some of our participants were first-time mothers, which suggests that they may have been more interested in nutrition-seeking behaviors due to the many changes that occur during pregnancy. In addition, self-reported pre-pregnancy weight was collected from the women to determine their respective group, EWG or RWG, and it is common for women to underreport their weight (Merrill \& Richardson, 2009; Kovalchik, 2009). Furthermore, many of our participants were likely transitionally low-income due to the study location. Therefore, some participants' health perceptions and dietary patterns may differ in the future due to change of income status. We also used a convenience sample of self-selected 
participants, which may not generalize to other low-income pregnant women. In addition, participants were recruited in only one county, Utah County, so it is unknown if these results would apply in other communities. This study provides important initial evidence that could be used to conduct a quantitative-based study with a larger sample size in the future.

While our study indicates the need for more nutrition education during and after pregnancy among low-income women in Utah, it is unknown if higher-income women (> 185\% of the poverty level) receive more nutrition education during pregnancy from their health care providers or if this lack of nutrition education holds true across all income levels. It was evident in our study that women were interested in making dietary changes during and after pregnancy for the health of their growing fetuses and infants and exercise changes after pregnancy to aid in weight loss. It is necessary that women receive proper nutrition education during this critical time to prevent excess weight gain rates from escalating and to avoid weight retention postpartum, which may lead to other adverse outcomes related to obesity, such as diabetes and cardiovascular disease. 


\section{References}

Abrams B, Altman SL, Pickett KE. Pregnancy weight gain: still controversial. Am J Clin Nutr. 2000;71:1233S-41S.

Amorim AR, Linne YM, Lourenco PMC. Diet or exercise, or both, for weight reduction in women after childbirth. Cochrane Database Systematic Reviews. 2008;4:1-42.

Bandura A. Social Learning Theory. Morristown, NJ: General Learning Press; 1971.

Bandura A. Social Learning Theory. New York, NY: General Learning Press, 1977.

Boscaglia N, Skouteris H, Wertheim EH. Changes in body image satisfaction during pregnancy: a comparison of high exercising and low exercising women. Aust N Z J Obstet Gynaecol. 2003 Feb;43(1):41-5.

Brawarsky P, Stotland NE, Jackson RA, Fuentes-Afflick E, Escobar GJ, Rubashkin N, Haas JS. Pre-pregnancy and pregnancy-related factors and the risk of excessive or inadequate gestational weight gain. Int J Gynecol Obstet. 2005;91:125-131.

Brown JE. Nutrition through the Life Cycle. California, 2008.

Chang MW, Nitzke S, Guilford E, Adair CH, Hazard DL. Motivators and barriers to healthful eating and physical activity among low-income overweight and obese mothers. J Am Diet Assoc. 2008;108:1023-1028.

Crowell DT. Weight change in the postpartum period. A review of the literature. J NurseMidwifery. 1995;40:418-423.

Crozier SR, Robinson, Godfrey KM, Cooper C, lnskip HM. Women's dietary patterns change little from before to during pregnancy. J Nutr. 2009;139:1956-64.

Devine CM, Bove CF, Olson CM. Continuity and change in women's weight orientations and lifestyle practices through pregnancy and the postpartum period: the influence of life course trajectories and transitional events. Soc Sci Med. 2000:50:567-582.

Downs DS, DiNallo JM, Kirner TL. Determinants of pregnancy and postpartum depression: prospective influences of depressive symptoms, body image satisfaction, and exercise behavior. Ann Behav Med. 2008 Aug;36(1):54-63.

Drewnowski A, Darmon N. Food choices and diet costs: an economic analysis. J Nutr. 2005;135:900-904.

Food and Nutrition Board. WIC Food Packages: Time for a Change. 2005. Available at: http://www.nap.edu/catalog.php?record_id=11280\#toc. Accessed June 15, 2010.

Fowles ER, Gabrielson M. First trimester predictors of diet and birth outcomes in low-income pregnant women. J Community Health Nurs. 2005;22:117-130. 
Fowles ER, Walker LO. Correlates of dietary quality and weight retention in postpartum women. J Community Health Nurs. 2006;23:183-197.

Fox S, Fallows D. Internet Health Resources. 2003. Available at:

http://www.pewinternet.org/Reports/2003/Internet-Health-Resources.aspx. Accessed February 9, 2010.

George CG, Hanss-Nuss H, Milani TJ, Freeland-Graves JH. Food choices of low-income women during pregnancy and postpartum. J Am Diet Assoc. 2005a;105:899-907.

George CG, Milani TJ, Hanss-Nuss H, Freeland-Graves JH. Compliance with dietary guidelines and relationship to psychosocial factors in low-income women in late postpartum. $J$ Am Diet Assoc. 2005b;105:916-926.

Gluelinckx I, Devlieger R, Beckers K, Vansant G. Maternal obesity: pregnancy complications, gestational weight gain and nutrition. Obes Rev. 2008;9:140-150.

Healthy People 2020. Available at: http://www.healthypeople.gov. Accessed February 9, 2010.

Hendrickson D, Smith C, Eikenberry N. Low-income individuals face limited fruit and vegetable access in 4 Minnesotan communities designated as food deserts. Agric Human Values. 2006;23:371-383.

Herman DR, Harrison GG, Afifi AA, Jenks E. Effect of a targeted subsidy on intake of fruits and vegetables among low-income women in the special supplemental nutrition program for women, infants, and children. Am J Public Health. 2008;98:98-106.

Hiddink GJ, Hautvast J, Vanwoerkum CMJ, Fieren CJ, Vanhof MA. Nutrition guidance by primary-care physicians - perceived barriers and low involvement. Eur J Clin Nutr. 1995;842851.

Institute of Medicine. Nutrition During Pregnancy: Part 1 Weight Gain. Washington, D.C.: National Academy Press;1990. Available at:

http://www.nap.edu/openbook.php?record_id=1451. Accessed January 18, 2010.

Kovalchik S. Validity of adult lifetime self-reported body weight. Public Health Nutr. 2009;12:1072-1077.

Lanigan J, Singhal A. Early nutrition and long-term health: a practical approach. Proceeding Nutr Soc. 2009;68;422-429.

Merrill R, Richardson JS. Validity of self-reported height, weight, and body mass index: findings from the National Health and Nutrition Examination Survey, 2001-2006. Prev Chronic Dis. 2009;6(4). Available at: http://www.cdc.gov/pcd/isues/2009/oct/08_0229.htm. Accessed April 5, 2010.

Morgan DL, Krueger RA. The Focus Group Kit. Vol. 1-6. Thousand Oaks, CA: Sage; 1998. 
Nuss H, Freeland-Graves J, Clarke K, Klohe-Lehman D, Milani TJ. Greater nutrition knowledge is associated with lower 1-year postpartum weight retention in low-income women. $J$ Am Diet Assoc. 2007 Oct;107(10):1801-6.

Odgen CL, Caroll MD, McDovell MA, Flegal KM. Obesity among adults in the United Statesno statistically significant change from 2003-2004. November 2007. Available at: http:/www.cdc.gov/nchs/data/databriefs/db01.pdf. Accessed June 16, 2008.

Olson CM. Tracking food choices across the transition to motherhood. J Nutr Educ Behav. 2005;27:129-136.

Phelan S. Pregnancy: a teachable moment for weight control and obesity prevention. Am J Obstet Gynecol. 2010;202:135.

Pomerance J, Johnson R, Kagal S, Brooks P, Margolin M, Allen A. Attitudes toward weight gain in pregnancy. West J Med. 1980 Oct;133(4):289-91.

Rallis S, Skouteris H, Wertheim EH, Paxton SJ. Predictors of body image during the first year postpartum:a prospective study. Women Health. 2007;45(1):87-104.

Rifas-Shiman S, Rich-Edwards JW, Kleinman KP, Oken E, Gillman, MW. Dietary quality during pregnancy varies by maternal characteristics in Project Viva: a US cohort. J Amer Diet Assoc. 2009;109:1004-11.

Richards R, Smith C. The impact of homeless shelters on food access and choice among homeless families in Minnesota. J Nutr Educ Behav. 2006a;38:96-105.

Richards R, Smith C. Shelter environment and placement in community affects lifestyle factors among homeless families in Minnesota. Am J Health Promot. 2006b;21:36-44.

Richards R, Smith C. Environmental, parental, and personal influences on food choice, access, and overweight status among homeless children. Soc Sci Med. 2007;65:1572-83.

Ritchie LD, Whaley SE, Spector P, Gomez J, Crawford PB. Favorable impact of nutrition education on California WIC families. J Nutr Educ Behav. 2010;42(3S):S2-S10.

Rose D, Richards R. Food store access and household fruit and vegetable use among participants in the US Food Stamp Program. Public Health Nutr. 2004;7:1081-8.

Sampselle CM, Seng J, Yeo S, Killion C, Oakley D. Physical activity and postpartum well-being. J Obstet Gynecol Neonatal Nurs. 1999 Jan-Feb;28(1):41-9.

Smith C, Richards R. Dietary intake, overweight status, and perceptions of food insecurity among homeless Minnesotan youth. Am J Hum Biol. 2008 May 19. [Epub ahead of print]

Story M, Neumark-Sztainer D, French S. Individual and environmental influences on adolescent eating behaviors. J Am Diet Assoc. 2002;102:S40-S51. 
Sutherland LA, Wildemuth B, Campbell, Haines PS. Unraveling the web: an evaluation of the content quality, usability, and readability of nutrition web sites. Nutr Educ Behav. 2005;37:300305.

Szwajcer EM, Hiddink GJ, Koelen MA, Van Woerkum CMJ. Nutrition-related informationseeking behaviours before and throughout the course of pregnancy: consequences for nutrition communication. Eur J Clin Nutr. 2005;59:S57-S65.

Task Force on Childhood Obesity. Solving the problem of childhood obesity within a generation. 2010. Available at: http://www.letsmove.gov/taskforce_childhoodobesityrpt.html. Accessed May 15, 2010.

Utah Department of Health. PRAMS Facts: Pregnancy Weight Gain in Utah. Available at: http://www.health.state.ut.us/rhp/pdf/Weight_Gain.pdf. Accessed June 16, 2008.

United States Department of Agriculture. WIC Frequently Asked Questions. Available at: http://www.fns.usda.gov/wic/FAQs/faq.htm. Accessed June 16, 2008.

Verbeke W, De Bourdeaudhuij I. Dietary behavior of pregnant versus non-pregnant women. Appetite. 2007;48:78-86.

Walker LO, Sterling BS, Timmerman GM. Retention of pregnancy-related weight in the early postpartum period: implications for women’s health services. JOGNN. 2005;34:418-427.

Walker LO. Weight-related distress in the early months after childbirth. West J Nurs Res. 1998 Feb;20(1):30-44.

Weaver K. Review: dietary restriction, with or without aerobic exercise, promotes weight loss in postpartum women. Evidence-Based Nursing. 2008;11(1):14. 


\section{Table I. Interview guide during and after pregnancy}

\begin{tabular}{|c|c|}
\hline During Pregnancy & After Pregnancy \\
\hline $\begin{array}{l}\text { How have your eating habits changed from before your pregnancy to now? } \\
\text { Prompts: } \\
\text { · What or who has influenced you to make changes? } \\
\text { - What are your perceptions of "eating for two" during pregnancy? } \\
\text { - What are some barriers, if any, to eating a healthy diet during } \\
\text { pregnancy? }\end{array}$ & $\begin{array}{l}\text { How have your eating habits changed since pregnancy? } \\
\text { Prompts: } \\
\text { · What has influenced these changes? } \\
\text { · What are some barriers, if any, to eating a healthy diet now } \\
\text { that your baby is born? } \\
\text { · For those who breastfeed their baby, how has your appetite } \\
\text { and eating patterns changed? }\end{array}$ \\
\hline $\begin{array}{l}\text { For those using WIC, what do you think about the foods provided in the } \\
\text { WIC packages? } \\
\text { Prompts: } \\
\text { · How adequate are the food packages for providing you with enough } \\
\text { food to eat during pregnancy? } \\
\text { · For those using WIC, how do you feel WIC benefits your health? } \\
\text { What are any concerns you have about WIC? }\end{array}$ & $\begin{array}{l}\text { For those using WIC, what do you think about the foods provided } \\
\text { in the WIC packages now that your baby is born? } \\
\text { Prompt: } \\
\text { · How adequate are the food packages for providing you with } \\
\text { enough food to eat? }\end{array}$ \\
\hline $\begin{array}{l}\text { Recently, the WIC Program approved a change to the food packages in } \\
\text { which fresh fruits and vegetables will be included on the vouchers. What } \\
\text { do you think about this change? }\end{array}$ & $\begin{array}{l}\text { What advice have you been given regarding nutrition and losing } \\
\text { weight after pregnancy? } \\
\text { Prompts: } \\
\text { - What advice have you received from your doctor or health } \\
\text { care provider? From family and friends? From WIC staff? } \\
\text { - What are your perceptions about the information given? }\end{array}$ \\
\hline $\begin{array}{l}\text { What advice have you been given about nutrition during pregnancy? } \\
\text { Prompts: } \\
\text { · What advice have you received from your doctor or health care } \\
\text { provider? From family and friends? From WIC staff? } \\
\text { · What are your perceptions about the information given? }\end{array}$ & $\begin{array}{l}\text { Are you concerned about losing postpartum weight? Can you tell } \\
\text { us more about that? } \\
\text { Prompts: } \\
\text { · If yes, how do you plan to lose the weight associated with } \\
\text { your pregnancy? } \\
\text { · If yes, what are some things you would like to do that you } \\
\text { aren't doing right now to lose weight? }\end{array}$ \\
\hline
\end{tabular}




\begin{tabular}{|c|c|}
\hline $\begin{array}{l}\text { How have your thoughts/attitudes about health changed since becoming } \\
\text { pregnant? }\end{array}$ & $\begin{array}{l}\text { How have your thoughts/attitudes about health changed now that } \\
\text { your baby is born? } \\
\text { Prompt: } \\
\text { · Have you experienced postpartum blues? Has this affected } \\
\text { your eating habits? }\end{array}$ \\
\hline $\begin{array}{l}\text { How have your exercise habits changed since becoming pregnant? } \\
\text { Prompt: } \\
\text { · What are some barriers, if any, to exercising during pregnancy? }\end{array}$ & $\begin{array}{l}\text { How have your exercise habits changed after pregnancy? } \\
\text { Prompt: } \\
\text { · What are some barriers, if any, to exercising after } \\
\text { pregnancy? }\end{array}$ \\
\hline
\end{tabular}


Table II. Demographic characteristics of interview participants $(\mathbf{n}=\mathbf{2 8})$ *

\begin{tabular}{|c|c|c|c|c|c|c|}
\hline & \multicolumn{3}{|c|}{ During Pregnancy } & \multicolumn{3}{|c|}{ Postpartum Follow-up } \\
\hline & $\begin{array}{c}\text { EWG, } \\
\text { mean (SD) } \\
(\mathbf{n}=13)\end{array}$ & $\begin{array}{c}\text { RWG, } \\
\text { mean (SD) } \\
(n=15)\end{array}$ & $\mathbf{P}$ value & $\begin{array}{c}\text { EWG, } \\
\text { mean }(S D) \\
(n=13)\end{array}$ & $\begin{array}{c}\text { RWG, } \\
\text { mean (SD) } \\
(\mathbf{n}=15)\end{array}$ & $P$ value \\
\hline Age (y) & $23.5(3.2)$ & $25.0(4.2)$ & 0.61 & -- & -- & \\
\hline Pre-pregnancy BMI & $24.8(4.8)$ & $21.3(2.4)$ & 0.02 & -- & -- & \\
\hline 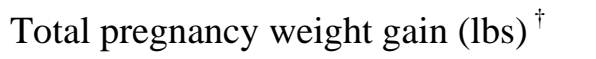 & -- & -- & & $41.3(14.1)$ & $31.2(6.3)$ & 0.02 \\
\hline $\begin{array}{l}\text { Number of children in household } \\
\text { Infant Characteristics }^{\dagger}\end{array}$ & $0.6(0.9)$ & $0.6(0.9)$ & 0.75 & -- & -- & \\
\hline $\begin{array}{l}\text { Birthweight (lbs) } \\
\text { Birth length (in) }\end{array}$ & -- & -- & & $\begin{array}{r}7.5(0.9) \\
18.7(5.4)\end{array}$ & $\begin{array}{r}7.7(1.3) \\
20.3(1.0)\end{array}$ & $\begin{array}{l}0.57 \\
0.29\end{array}$ \\
\hline $\begin{array}{l}\text { Income } \\
\text { Less than } \$ 5,000 \\
\$ 5,001-\$ 9,999 \\
\$ 10,000-\$ 19,999 \\
\$ 20,000-\$ 39,999 \\
\text { Greater than } \$ 40,000\end{array}$ & $\begin{array}{r}0(0) \\
2(15) \\
7(54) \\
3(23) \\
1(8)\end{array}$ & $\begin{array}{r}2(13) \\
2(13) \\
6(40) \\
5(33) \\
0(0)\end{array}$ & 0.49 & $\begin{array}{r}0(0) \\
2(15) \\
9(70) \\
2(15) \\
0(0)\end{array}$ & $\begin{array}{l}1(7) \\
4(27) \\
3(20) \\
5(33) \\
2(13)\end{array}$ & 0.10 \\
\hline $\begin{array}{l}\text { Education } \\
\text { Some college } \\
\text { Completed college } \\
\text { Completed grad/professional school }\end{array}$ & $\begin{array}{r}8(62) \\
5(39) \\
0(0)\end{array}$ & $\begin{array}{r}6(40) \\
8(53) \\
1(7)\end{array}$ & 0.40 & $\begin{array}{r}6(46) \\
7(54) \\
0(0)\end{array}$ & $\begin{array}{l}4(27) \\
9(60) \\
2(13)\end{array}$ & 0.28 \\
\hline $\begin{array}{l}\text { Government Assistance Usage } \\
\square \text { WIC } \\
\square \text { SNAP }\end{array}$ & $\begin{array}{r}6(46) \\
1(8)\end{array}$ & $\begin{array}{r}5(33) \\
0(0)\end{array}$ & $\begin{array}{l}0.70 \\
0.46\end{array}$ & $\begin{array}{l}8(62) \\
2(15)\end{array}$ & $\begin{array}{r}6(40) \\
0(0)\end{array}$ & $\begin{array}{l}0.40 \\
0.21\end{array}$ \\
\hline Perception of health & & & 0.07 & & & 0.82 \\
\hline Excellent & $2(15)$ & $3(20)$ & & $2(15)$ & $2(13)$ & \\
\hline Very Good & $7(54)$ & $12(80)$ & & $7(54)$ & $8(53)$ & \\
\hline Good & $4(31)$ & $0(0)$ & & $4(31)$ & $4(27)$ & \\
\hline Fair & $0(0)$ & $0(0)$ & & $0(0)$ & $1(7)$ & \\
\hline Perception of weight ${ }^{\ddagger}$ & & & 0.03 & & & 0.04 \\
\hline
\end{tabular}


Weigh too much

Weigh the right amount

Weigh too little

Exercise Behaviors

Postpartum intention to exercise

Currently exercising

Breastfeeding

BMI = Body Mass Index; EWG = Excess Weight Gainer; RWG = Recomm
* One EWG participant was excluded because she was pregnant with twins.
${ }^{\dagger}$ Based on participant responses on the post-partum sociodemographics survey

${ }^{\ddagger}$ During pregnancy, this refers to perceptions of weight gain. In the post-partum period, this refers to participants’ perceptions of their current weight at the post-partum follow-up interview session.

$\square$ WIC = The Special Supplemental Nutrition Program for Women, Infants, \& Children; SNAP = Supplemental Nutrition

Assistance Program (formerly known as Food Stamps).

\begin{tabular}{rrrrrr}
$3(23)$ & $0(0)$ & & $11(85)$ & $6(40)$ & \\
$9(69)$ & $15(100)$ & & $2(15)$ & $8(53)$ & \\
$1(8)$ & $0(0)$ & & $0(0)$ & $1(7)$ & \\
& & & & & \\
$3(100)$ & $14(93)$ & 0.52 & -- & -- & - \\
$8(40)$ & $12(60)$ & 0.18 & $9(69)$ & $10(67)$ & 0.60 \\
-- & -- & -- & $11(85)$ & $13(93)$ & 0.50 \\
\hline
\end{tabular}

$11(85)$

0.50 
Table III. Selected quotes to illustrate main themes and subthemes.

\section{Theme: Subtheme}

Health Perceptions and Behaviors during Pregnancy:

Awareness of Dietary Intake and Baby's Health
Quotations from EWG and RWG

- "It's just a little more important to be healthy and eat healthy now so that your baby can be healthy...it's more important for me to be healthy because I'm directly affecting the health of someone else.” (EWG)

- "To have a healthy baby I have to eat healthy." (RWG)

- "I don't want to say pressure but [I have] a responsibility to give nutrients to somebody else cause even though I should be doing it just for myself initially...the motivation to have a healthy baby and when I eat healthy I've noticed that I feel a lot better and especially being pregnant with low energy and stuff you need to make sure to get all those nutrients." (RWG)

- "If I'm going to eat something I try and make it worth the calories so at least the baby is getting some nutrition instead of my stomach just getting filled up.” (EWG)

- "I guess I don't care enough about me, but I care enough about my baby to worry about eating." (EWG)

- "I've been really good with [taking a supplement] because I feel it's really important. I feel like so much more is at stake...there's a baby involved. It's more important to take it." (RWG)

- "I think I eat very similar to the way [my mom] cooked when we were young. She made almost everything from scratch and we did a lot of cooking..whole wheat bread instead of white bread and real cheese instead of processed cheese..I think my [eating habits] are actually pretty similar [as before pregnancy].” (RWG)

- "When I'm not pregnant I don't care what I eat..I'm not careful about eating cause I'm just so busy." (EWG)

EWG v. RWG during Pregnancy: Eating Patterns

- "Honestly [my eating habits] haven't changed..most of my money is spent on produce and I make my own whole wheat bread..I've just had more snacks during the day so I'll still have my three meals and then I just get more hungry and so I just eat when I get hungry." (RWG)

- "I'm not positive that I would say [my eating habits] have changed that much because I went into pregnancy with the dietetics mind I guess with a strong belief in the value of good health and I still believe in the value of good health and I always knew it was important for babies as well.” (RWG) 
EWG v. RWG during Pregnancy: Nutrition and Weight Gain Knowledge

Nutrition Advice during Pregnancy: Health Professionals

- “Once I got pregnant they say you're not suppose to diet and for awhile so like everything I learned in my weight management class kind of flew out the window and I would just eat whatever...I've been a lot more lax with my diet since being pregnant..I've been worried because they say don't diet so I didn't want to hurt the baby or anything." (EWG)

- "Healthy is if [food] doesn't have a lot of creamy stuff in it and if it has vegetables and protein and [is] balanced..I sort of feel like I didn't serve something good if I didn't put a vegetable or a fruit with it." (RWG)

- "Other things I've read is you only need an extra 300 calories a day so pop on down to McDonald's and get a small French fry and you're good.” (EGW)

- "I'm really not too excited about [my doctors] but it's just one of the doctors that Medicaid offers, like a group of doctors, so I always see different doctors and they have so many patients and so I feel rushed. So I just figured they'll tell me what I can read in a book anyway." (RWG)

- "You go in there and you don't really know what to ask. They'll say, "well do you have any questions?" and it's like I don't even know what I should be asking...and first time pregnancy. It's like, I don't know!” (EWG)

- "He’ll give me advice when I ask for it, but he doesn’t offer it.” (RWG)

- "They haven't said your weight gain is too low, too high. They haven't told me what to eat...and they kind of assume that you have no questions and they're always really in a hurry...I sometimes wonder why we go to the appointments.” (RWG)

- "Everything looks good and so I think [my doctor's] haven’t been concerned about it." (EWG)

- “He doesn’t even talk about my weight gain at the doctor's appointments which I assume that just means that I'm fine weight gain wise and he would say something if it was either too much or too little.” (EWG)

- "[My husband] has read some books that say the homogenization process really isn't good for you to drink it [so] he gets raw milk from where he works. We get raw milk." (EWG)

Nutrition Advice during Pregnancy: Family and Friends
- "[My mother-in-law] didn't gain anymore weight after 20 pounds..she said that the baby is still growing but he isn't gaining a whole lot and that he can just take from me what he needs..I think she suggested I stop [gaining weight at 20 pounds].” (EWG)

- "There's people who say 'just eat more, like here you're pregnant you need to eat more..here just have more everything'..try to like push you..there's tons of justification all around you about like it's okay to eat whatever you want, which I don't agree with.” 


\section{(RWG)}

- 'I mean if anything [my family] says, 'Oh you're pregnant, you can eat that.' It's almost like being pregnant is the excuse to eat junk food. That seems to be the perception of everybody around. I don't really just buy into that.” (RWG)

- "The only advice my family members have given me is to watch my weight and I've already gained about 40 pounds and I have 3 months left to go so they are a little bit concerned but honestly I don't quite know where it is going." (EWG)

- "I'm trying to remember what I read you need an extra 300 calories a day or something like that." (RWG)

- "I've done more research online and I think from that I've learned..I saw recommendations for only eating maybe two cans of tuna week while you're pregnant because of mercury levels or stuff like that.” (RWG)

Nutrition Advice during Pregnancy: Media Resources
- "I have one book that is called What to Expect When Expecting so I’ve read that a lot and there's a website called Babycenter.com and I've become a member of that site...it's just nice if I have a question I can go on there and search it and see if someone else has said the same question and what people said about it so that's been nice.”

\section{(EWG)}

- "We just looked [nutrition information] up [on the internet] and did our own thing there and decided what to watch for and stuff..I usually check [internet sources] with a few different places that I'll go to and [see] if they agree.” (EWG)

- "I [am] really worried about [weight loss] because even though I ate really well during my pregnancy I still gained 66 pounds..I look back at the pictures and think, "Oh my gosh!" It's kind of difficult now because even though I'm eating less than normal I'm kind of staying about where I am so I still have about 30 pounds to lose.” (EWG)

- "When you leave the hospital you still look like you're 6 months pregnant. Likes it's weird because your stomach is still so stretched. You're like, 'wait a second I didn't know I'd still look like I was pregnant.' So I think trying to lose that is my main focus...I just kind of assumed that once he came out that my stomach would be kind of normal, but it just takes longer than I realized.” (EWG)

- "Overall I'm pretty satisfied [with my weight]. I feel like I lost the weight pretty quick. I'm not like dissatisfied with my body." (RWG)

- "I felt like I ate healthy my whole pregnancy and I feel like I've eaten healthy for the most part since so I figured it would come off and I think there will still be a few pounds that won't come off till I finish breastfeeding. That's fine.” (RWG)

- "I'm amazed at how quickly my body bounced back without me doing very much so I
Experiences after Pregnancy:

Weight Loss 
think once I get into the swing of things and start exercising more regularly I think I'll be fine.” (RWG)

- "I just look at my baby and I don’t want him to be unhealthy. I don’t want to ruin his chances for a healthy, happy life so that affects how I eat...like not wanting to eat too much junk food and wanting to get enough nutrients for him and it encourages me to take my prenatal vitamin as well still.” (EWG)

- "I think that being healthy is so much more important because I want to be alive for a really long time and be really healthy to be able to play with my kids and my grandkids...the importance of [health] has really been stressed.” (RWG)

Experiences after Pregnancy:

Health Attitudes and Baby's Health
- "Before I wanted to eat healthy because she was in me and I wanted to make sure she was getting everything that she needed, but since I'm still breastfeeding that's still a concern since I'm her only source of nutrients right now. I still want to make sure she's getting what she needs." (EWG)

- "I think during pregnancy I ate more and I thought a lot about what would be healthy for the baby and I feel like it's that way now because I'm breastfeeding. Whatever I eat really does affect her." (RWG)

- "I've always thought health is important. Now I think it's more important so that I'm around when she has her kids so it's a more long term view I think and I would like to do everything now that I can to increase my longevity.” (RWG) 


\section{APPENDICES}

Appendix A: Literature Review

Appendix B: Methods

Appendix C: Recruitment Flyer

Appendix D: Telephone Screening for Research Study Eligibility

Appendix E: Baby Your Baby Weight Gain Charts

Appendix F: Statement of Informed Consent

Appendix G: Interview Questions during Pregnancy

Appendix H: Interview Questions after Pregnancy

Appendix I: Demographics Questionnaire during Pregnancy

Appendix J: USDA’s Food Security Scale

Appendix K: Demographics Questionnaire after Pregnancy 


\section{Appendix A}

\section{LITERATURE REVIEW}

Obesity rates have dramatically increased in the United States (US), including women in their child-bearing years, with the most recent estimates of 30\% of females aged 20-39 years having a body mass index(BMI) > 30 (Ogden et al, 2007). Recently, in the state of Utah, the Pregnancy Risk Assessment Monitoring System Program reported that approximately 50\% of pregnant women gained an excessive amount of weight during pregnancy, suggesting this is a significant public health issue in the state (Utah Department of Health, 2008).

\section{Excess Weight Gain}

Prior research has suggested pre-pregnancy obesity and excessive weight gain during pregnancy as risk factors for macrosemia, cesarean delivery, and postpartum weight retention, which if sustained long-term can lead to adverse health consequences associated with adult obesity, such as diabetes and heart disease (Abrams et al, 2000; Brawarsky et al, 2005; Fowles and Walker, 2006). Other studies have evaluated changes in dietary intake from pregnancy to the postpartum period, with common findings indicating increased fat intake and inadequate fruit, vegetable, and whole grain intake (George et al, 2005a; Fowles \& Gabrielson, 2005; Verbeke and De Bourdeaudhuij, 2007). Furthermore, women who have a history of dieting in order to lose weight prior to pregnancy have often been shown to overeat during pregnancy, to experience unhappiness with their body changes throughout their pregnancy, and to plan to diet to lose weight during postpartum (Devine et al, 2000). Recently, Olson (2005) evaluated factors influencing excessive weight gain during pregnancy and found that limited discussion of weight gain by health care providers, increased caloric intake, decreased fruit and vegetable consumption and exercise habits, and living in poverty ( $<185 \%$ of the poverty line) were 
significant risk factors. A similar study found that pregnant women who were young, less educated, had more children, and had a higher pre-pregnancy BMI were more likely to have lower-quality diets than other pregnant women (Rifas-Shiman et al, 2009).

\section{Nutrition Knowledge and Education}

According to the Institute of Medicine, women should be receiving nutrition counseling before, during, and after pregnancy in order to improve the quality of their diets and their overall health (Institute of Medicine, 1990). According to a study conducted among Dutch women in their first trimesters, pregnant mothers have an increased awareness about their dietary intake for the sake of their babies' health and development (Szwajcer et al, 2005). Based on current published research, it appears that similar studies have not been conducted in the United States. Although many pregnant women reported being more conscious of their dietary intake, one study found that most women do not significantly improve their diets during pregnancy compared to before pregnancy (Crozier et al, 2009).

Regardless of how women eat during pregnancy, they seek out nutrition information. The internet and social networks have been reported as the most common places women turn to for nutrition advice and education (Szwajcer et al, 2005; Sutherland SA et al, 2005). As of December 2002, about 80\% of adult Americans relied on the internet for nutrition education and

resources. Because there is a lack of editorial control over what can be posted on websites, many internet-users are often receiving inaccurate nutrition information (Fox \& Fallows, 2003). Furthermore, one study found that perceptions of website credibility were based on website design, the website provider, and text that did not include "too much professional terminology", all of which are inappropriate measures for determining credibility (Sutherland et al, 2005). 
One of Healthy People 2020's objectives has been to "increase the proportion of patients whose doctor recommends personalized health information resources to help them manage their health.” By doing so, this may contribute to women reaching another Healthy People 2020 objective to "increase the proportion of mothers who achieve a recommended weight gain during their pregnancies.” However, there are barriers that need to be overcome in order for this goal to be achieved. Hiddink et al (1995) studied physicians’ perceived barriers for providing nutrition education to their patients. Seventy percent of physicians felt that nutrition plays an important role in health, but only twenty-eight percent of physicians provided nutrition education for approximately ten percent of their patients. Furthermore, fourty-eight percent of physicians talked to only about five percent of their patients regarding nutrition. The reason for these low statistics was mainly due to physicians' lack of nutrition knowledge, lack of time, and beliefs that patients do not care about changing their dietary habits (Hiddink et al, 1996). Although nutrition appears to be important to physicians, based on this study it appears that most patients are not being provided with education.

Because physicians have perceived barriers for providing proper nutrition education during pregnancy many women are unaware of how much weight should be gained during pregnancy and they do not feel that their doctor would be concerned about too little weight gained during pregnancy. Pomerance et al (1980) suggests that many women and some doctors do not understand the importance of proper weight gain and nutrition during pregnancy. Lay and professional education may be needed for pregnant women to understand nutritional concerns during pregnancy (Pomerance et al, 1980).

Nutritional knowledge has been shown to impact postpartum weight retention, which could be provided by doctors and other healthcare providers. Women with nutritional 
competency tend to retain less than $5 \%$ of their weight gained during pregnancy, and those with little to no nutritional knowledge retain 5\% or more of weight gained during pregnancy. In addition, Caucasians tend to have higher nutrition knowledge scores than non-Hispanic blacks and Hispanics (Nuss et al, 2007). If doctors and other healthcare providers educated pregnant women about nutrition and living a healthy lifestyle, then fewer women would be more likely to retain excess weight postpartum.

\section{Low-Income Population Risks}

Low-income pregnant women have access to government food assistance programs, such as the Special Supplemental Nutrition Program for Women, Infants, and Children (WIC), which aim to educate eligible women on healthy dietary habits and appropriate weight gain during pregnancy and to provide vouchers to improve access and intake of healthy foods as a means to enhance pregnancy outcomes. In Utah, WIC currently provides monthly vouchers worth approximately \$32 per person. These vouchers can be used to purchase milk, eggs, cereal, bread, beans, and juice. Furthermore, a new policy change in 2009 has allowed WIC participants to also receive fresh fruits and vegetables and whole grain products to further benefit their health (United States Department of Agriculture, [no date]). Changes were made to the old WIC vouchers to coincide with current dietary recommendations by providing more foods that may decrease risk of obesity and diet-related disease, and to further enhance pregnancy and postpartum health outcomes among this population (Food and Nutrition Board, 2005). Prior to this policy change, Herman et al (2008) tested for the effectiveness of produce vouchers among low-income women in the postpartum period. By the end of the 6-month intervention, participants had increased their consumption of fresh fruits and vegetables by 0.8 to 1.4 servings; at the 6-month follow-up, participants continued to consume more fresh produce than before the 
intervention. It was anticipated that the new WIC vouchers would help to increase fruit and vegetable consumption among low-income women (Herman et al, 2008).

Despite government food assistance efforts, women continue to gain excessive amounts of weight during pregnancy and retain the weight in the postpartum period (Utah Department of Health, 2008; Guelinckx et al, 2008; Crowell, 1995; Walker et al, 2005). Unhealthy eating habits often continue to occur during the postpartum due to the many changes women are faced with after giving birth. Low-income women are especially faced with intensive stress due to limited finances, poor access to child care, lack of transportation, and inadequate time for food preparation (George et al, 2005b; Chang et al, 2008).

Research has indicated the community environment, especially in urban areas, as a significant risk factor for poor dietary habits among low-income populations (Smith \& Richards, 2008; Richards \& Smith, 2006a; Richards \& Smith, 2007). Urban areas have been classified as food deserts, meaning a limited amount of food resources within a specific geographical area, which have equated into limited access to an adequate, healthy food supply and subsequent dietary intake (Rose \& Richards, 2004; Hendrickson, Smith \& Eikenberry, 2006; Richards \& Smith, 2006b). Drewnowski and Darmon (2005) showed that high-caloric, low nutrient dense foods, foods often available in urban areas, tend to be more cost efficient than healthier food items, which can be appealing for those with limited economic resources. Furthermore, lowincome populations have been shown to have greater food expenditures because of limited food resources in urban areas and associated higher food costs (Richards and Smith, 2006b; Hendrickson, Smith \& Eikenberry, 2006). 


\section{Body Image Postpartum}

Women who exercise during pregnancy are more accepting of their bodies' changes early on in their pregnancy compared to women who do not exercise regularly, which is similar to non-pregnant females who exercise consistently (Boscaglia et al, 2003). Exercising during pregnancy also impacts weight retention postpartum. Research suggests that the more active women are during pregnancy, the less weight they will retain postpartum compared to less active women. In addition, women who exercise vigorously during pregnancy tend to adapt quicker postpartum and are more likely to participate in a variety of activities compared to non-exercisers (Sampselle et al, 1999).

Depressive symptoms, body image dissatisfaction, and lack of exercise correlate with one another, and depressive symptoms and body image satisfaction often determine depression during pregnancy and in the postpartum period (Downs et al, 2008). In addition, women are most dissatisfied with their bodies at around 6 months postpartum. As a result, depressive symptoms, dieting behaviors, and exercising regularly at 6 months postpartum are predictors of body image (Rallis et al, 2007; Boscaglia et al, 2003).

Other studies have determined risk factors for feeling distressed and dissatisfied with postpartum weight. One such study found that higher pre-pregnancy body mass index, larger gestational weight gain, higher current postpartum body mass index, less healthy lifestyle, and greater body image dissatisfaction were risk factors for weight-related depression (Walker, 1998). The results from this particular study elucidated that doctors and other healthcare specialists need to address the psychosocial issues that result from childbearing, particularly postpartum weight issues (Walker, 1998). 


\section{Theoretical Model}

Health behavior theories have been extensively used in nutrition-related research to evaluate factors influencing specific dietary and exercise behaviors as well as overall health status. One such theory, the social cognitive theory, postulates a dynamic, triadic relationship between three constructs - the environment, behavior, and personal factors, meaning as one construct is altered the other factors are reciprocally affected (Bandura, 1971; Bandura, 1977). Prior research among low-income populations has used the social cognitive theory to evaluate factors influencing food choice, food access issues, and dietary intake, with results indicating the interplay between constructs in the theory (Richards \& Smith, 2006a; Richards \& Smith, 2006b; Story et al., 2002)

Although prior research has indicated changes in actual dietary intake and eating patterns during pregnancy and risk factors for postpartum weight retention, limited research has used a theoretical approach to evaluate factors influencing food choice and health perceptions among low-income women during pregnancy and how these factors change in the postpartum period.

Thus, this study uses the underlying constructs of the social cognitive theory as a theoretical framework to address the following research question:

What factors influence eating patterns, weight status, and health perceptions during pregnancy and in the postpartum period among low-income women participating in or income-eligible (<185\% poverty level) for the WIC Program?

\section{Potential Implications}

Results from this study may have implications for nutrition educators and policymakers, in that the researchers will be able to provide additional information about how pregnant women who are receiving or are eligible (based on income) to receive food assistance programs can be 
better served. Perceptions of food assistance programs on health and eating patterns, how foods choices are made during and after pregnancy, and how this changes over the course of pregnancy and the postpartum period will be assessed. Results from this study will provide insights for addressing food inequities among low-income pregnant women and offer an opportunity to propose changes in policy that may aid in promoting healthier behaviors for low-income women during pregnancy and in the postpartum period. This study will also provide information about factors influencing eating and exercise patterns during and after pregnancy, which may offer insight as to future nutrition education intervention studies and/or programs to help promote healthy behaviors during pregnancy and in the postpartum period among low-income women. 


\section{Appendix B}

\section{METHODS}

This study was a longitudinal descriptive study design consisting of both qualitative and quantitative methodologies, which consisted of two time periods: (1) initial interviews with pregnant women at least seven months gestation and (2) follow-up interviews at 2-4 months postpartum. Brigham Young University’s Institute Review Board approved this study.

\section{Eligibility Requirements}

For time one, low-income women who were currently participating in the WIC Program or were income-eligible for the WIC Program, who were at least seven months pregnant, and resided in Utah County were recruited for this project. Women needed to be at least seven months pregnant to reduce risk of loss to follow-up. Furthermore, the third trimester is a time when eating habits are more likely to become stable compared to the first two trimesters of pregnancy when nausea and vomiting is more common (Brown, 2008). Eligibility for the WIC Program includes having an annual household income $<185 \%$ of the poverty level based on household size, having a nutritional risk factor (e.g., iron deficiency, overweight/obese), and living within the local service area (e.g., Utah County). Thus, individuals who currently participated in WIC or who have an annual household income $<185 \%$ the poverty level were eligible for this study.

\section{Exclusion Criteria}

Exclusion criteria included women $<18$ years of age, women gaining an inadequate amount of weight based on the Institute of Medicine’s weight gain recommendations, and women who were not fluent in English. It was anticipated that adolescent pregnant women's 
shopping, cooking, and dietary consumption patterns may differ from adult pregnant women, thus they were excluded. The underlying premise for this project was to determine factors associated with excessive weight gain during pregnancy; the researchers anticipated that the experiences of women gaining an inadequate amount of weight during pregnancy would vary substantially from excess weight gainers and would be outside the scope of this research project. Hence, these women were excluded from the study. All study participants had to be fluent in English in order to alleviate any bias that may have arose with the use of translators.

\section{Time 1: During Pregnancy}

The topics of interest were the effects of weight gain during pregnancy on food choice and health perceptions; hence, individual interviews were conducted with women who were within the weight recommendations for their current weeks of gestation and those who were exceeding their weight recommendations.

\section{Recruitment Methods}

Fliers were posted at local low-income community centers and college campuses for recruiting (Appendix C). A screening form was used to determine eligibility and to classify participants into their respective groups, excess weight gainer (EWG) or recommended weight gainer (RWG) (Appendix D). Criteria for evaluating weight gain was based on women's prepregnancy body mass index (BMI), calculated using a women's pre-pregnancy weight (kg) and height (m). After obtaining the women’s pre-pregnancy BMI, the Baby Your Baby’s Pregnancy Weight Gain chart, which is based off of the Institute of Medicine's recommendations, was used to assess weight gain, based on the women's weeks of gestation and pre-pregnancy BMI. If a woman fell within the recommended range, she was considered a RWG. If she is above the 
recommended weight gain range, she was considered a EWG. These terms were only used by the researchers to classify participants into their correct categories.

Twenty-nine interviews were conducted for this study (15 participants classified as EWG and 14 classified as RWG). Saturation was used to determine the final sample size (Kreuger \& Morgan, 1998). Interviews took place on the BYU campus. Participants were asked to complete a statement of informed consent before interviews started (Appendix E) and were asked questions about food choice and health perceptions during pregnancy (Appendix F) and the postpartum period (Appendix G).

\section{Interview Questions during Pregnancy}

For those currently receiving WIC benefits, questions were asked about perceptions of the program on obtaining an adequate food supply, making food choices, and effectiveness in providing health and nutrition information during pregnancy and in the postpartum period (Appendix F). Participants also completed a sociodemographic information sheet (Appendix H), and the United States Department of Agriculture's Food Security Scale in order to evaluate household food security status in the past 30-days (Appendix I). Anthropometric data were collected via a portable stadiometer to the nearest $0.01 \mathrm{~cm}$, with participants removing shoes; a portable scale was used to measure weight to the nearest $0.01 \mathrm{~kg}$, with participants' shoes and heavy outer clothing removed. In addition, 24-hour recalls were collected at the beginning of each interview. Three dimensional food models and standard household measuring tools were used for improved accuracy. Participants received a \$20 gift card for their participation in the during pregnancy interview. 


\section{Time 2: Postpartum Period}

At time 2, the pregnant women who participated in time 1 were followed-up 2 to 4 months postpartum through the same qualitative and quantitative methods described in time 1; however, the sociodemographics information sheet (Appendix J) and interview questions and prompts were altered to be more appropriate for the postpartum period (Appendix G).

\section{Data Analysis}

Interviews were analyzed using standard procedures (Morgan and Krueger, 1998). Interviews were audio-taped and transcribed verbatim, and subsequently evaluated independently by two researchers. Any discrepancies in coding between the researchers were reconciled and common themes that emerged were discussed. Transcripts were evaluated both collectively and separately. The main ideas from the transcripts were discussed, summarized, and tallied to determine the most commonly reoccurring codes and how these varied between the two groups (RWG vs. EWG). Common themes and subthemes emerged based on this evaluation.

Descriptive statistics (means, frequencies, etc.) were used to evaluate sociodemographic and anthropometric variables and food security status at each individual time point. Student ttests and chi-square statistics were used to compare subjects' responses between the pregnancy period and postpartum follow-up. 


\section{Appendix C}

\section{Are you at least}

\section{7 months pregnant?}

Would you be willing to talk about the food choices you make and your thoughts on health and diet during and after your pregnancy?
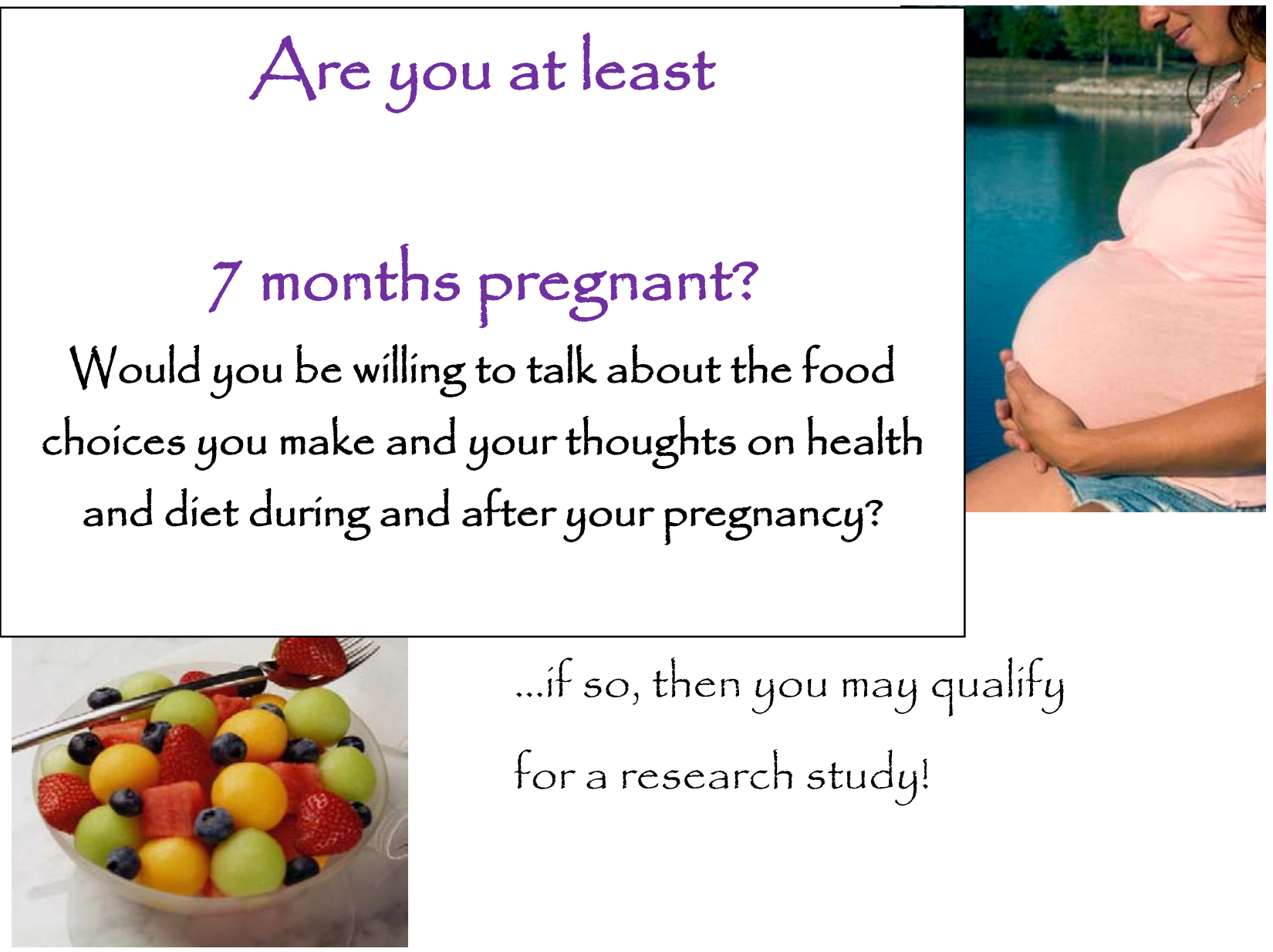

...if so, then you may qualify

for a research study!

-We are interviewing women about what influences their food choices and exercise patterns during pregnancy. There will also be a 2 to 4 month follow-up interview after your baby is born to talk about how your eating and exercise patterns may have changed from pregnancy.

- Participants will be given a $\$ 20$ gift card for their time (about 1 1/2 hours in taking part in the pregnancy interview. They will receive an additional $\$ 20$ gift card for participating in the 2 to 4 month follow-up interview.

If you are interested please contact Tianna Watson by phone at 801-473-7740 or by email at ti watson@byu.edu. 


\section{Appendix D}

TELEPHONE SCREENING FOR RESEARCH STUDY ELIGIBILITY

Date:

Thank you for your interest in our research study. My name is Tianna Watson, a graduate student from the Department of Nutrition, Dietetics and Food Science at Brigham Young University and I am working with Dr. Rickelle Richards, a faculty member in our department. I would first like to tell you more about our study and find out your interest in taking part in our study. We are conducting discussion groups with women who are at least 7 months pregnant to learn more about factors that influence your food choices and exercise patterns during pregnancy, how these may have changed from before pregnancy, and any changes in eating and exercise patterns that may occur after pregnancy.

Before I tell you about the study in more detail, can I ask you a few questions to see if you are eligible for this study? This screening is voluntary and will take about 10-15 minutes. All responses are confidential. May I proceed?

Screening Questions

1) How many weeks have you been pregnant? wks

2) Are you currently a student at a University (e.g. BYU, UVU, U of U)? $\square$ Yes No $\square$

3) Are you currently on any type of food assistance program, like WIC or food stamps? $\square$ Yes $\quad$ No $\square$

4) If no to Question \#3, then ask how many people are in your household?

\begin{tabular}{|c|l|}
\hline Household Size & \multicolumn{1}{|c|}{ Annual Income (<185\% Poverty Level) } \\
\hline 1 & $<\$ 19,200$ \\
\hline 2 & $<\$ 25,900$ \\
\hline 3 & $<\$ 32,560$ \\
\hline 4 & $<\$ 39,220$ \\
\hline 5 & $<\$ 45,880$ \\
\hline 6 & $<\$ 52,540$ \\
\hline 7 & $<\$ 59,200$ \\
\hline 8 & $<\$ 65,860$ \\
\hline For each additional person, add & $\$ 6,600$ \\
\hline
\end{tabular}


5) Do you earn less than [depending on number of people in household]? $\square$ Yes $\quad$ No $\square$

6) Do currently live in Utah County or Salt Lake County? Utah County Salt Lake County

8) What is your current height?

9) How much did you weigh before you became pregnant (or what was your weight before pregnancy)? _ l l _ _ _

(Insert BMI chart here to figure out their BMI)

10) How much weight have you gained so far in your pregnancy?___ lbs

(Using pre-pregnancy BMI, current weeks gestation and weight gain, use IOM's weight gain chart to classify if gaining recommended amount of weight or excess weight)

ELIGIBILITY - $\square$ Yes $\quad \mathrm{No} \square$

If no, from the information you have given me so far, it looks like you are not eligible for this study. However, there may be other studies conducted in the future that you might be eligible for. Thank you for your time and have a nice day.

OR

If yes, from the information you have given me so far, it looks like you are eligible for this study.

Let me tell you about the study in a little more detail.

As I mentioned before, we want to learn more about factors that influence your eating and exercise habits during pregnancy and after your baby is born. By agreeing to take part in this study, you agree to take part in 2 discussion groups: one will be while you are pregnant and the other will be 2-4 months after you have your baby.

Part 1 (Interview during pregnancy): During the interview you will be asked to share your thoughts and experiences about how you decide what to eat, how your eating habits have changed since becoming pregnant and the factors that influence these changes, and what your thoughts are on food and exercise habits during pregnancy. So we will not miss any of the comments made by those taking part in the interview, we will be audio-recording the interview. Only your first name will be attached to the transcript. Your height and weight will also be measured. The discussion group will last about $1 \frac{1 / 2}{2}$ hours. You will receive $\$ 20$ for your time in taking part in the interview and having your height and weight measured.

Time 2 (2 to 4 month Follow-up Interview): Two to four months after your baby is born, you will be asked to take part in a follow-up interview to share your thoughts and experiences about how your eating and exercise habits have changed after you have had your baby, how people around you influence these changes, any health concerns you have after pregnancy, and how you feed your baby. So we will not miss any of the comments made by those taking part in 
the follow-up interview, we will also audio-record the discussion. Only your first name will be attached to the transcript. You will also be asked to give information about your gender, educational level, the number of children in your household, if you are taking any dietary supplements, and how you feel about your overall health. Your height and weight will also be measured. The interview will last about $1 \frac{1}{2} 2$ hours. You will receive an additional $\$ 20$ for your time in taking part in the interview and having your height and weight measured.

Risks and Benefits

There are no benefits to you in taking part in this research study. There are minimal risks for participation in this study. The risk in taking part in this study are that we will be asking you personal questions, such as thing that influence your eating and exercise habits, during the pregnancy interview (Time 1) and on the 2 to 4 month follow-up interview (Time 2).

Confidentiality

All information collected (from Time 1 - the pregnancy discussion group and Time 2 - the 2 to 4 month follow-up interview) will be kept private, in a locked file cabinet in Dr. Rickelle Richards’ office. Only Dr. Rickelle Richards and Tianna Watson will have access to the collected information. The information collected may be published. Your privacy will be protected and will not be identified in anyway. No individual information will be released.

Are there any other questions that I can answer for you? $\square$ Yes $\quad$ No $\square$

Would you be interested in taking part in both the interview during pregnancy and the 2 to 4 month follow-up interview? $\square$ Yes No $\square$

The interview would be held on ........../2008 at BYU,

Number of screens/invited to participate. Information is being kept anonymous.

Name:

Date of Screen:

Phone number/e-mail:

Interview Schedule, Time 1: [date]

Circle one: Recommended weight gain group Excess weight gain group 


\section{Appendix E}

\section{Pregnancy Weight Gain Chart in Pounds}

Pre-pregnancy BMI $<18.5,28-40$ pounds

If your pre-pregnancy BMI is less than 185 , then the recommended weight gain range for your

pregnancy is 28 to 40 pounds. The blue area shows the weight gain recommendation.

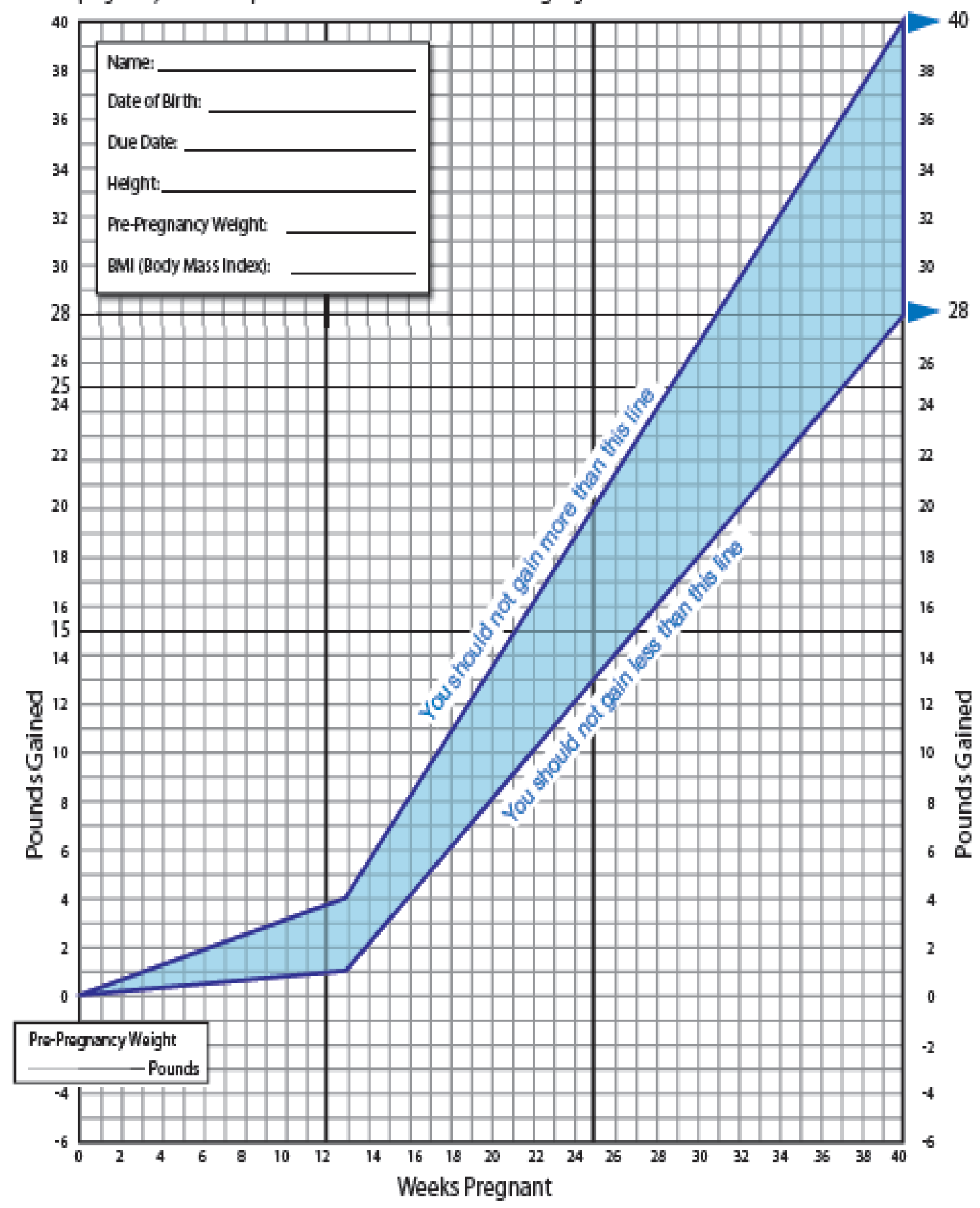




\section{Pregnancy Weight Gain Chart in Pounds}

Pre-pregnancy BMI 18.5-24.9, 25-35 pounds

If your pre-pregnancy BMI i between 185 and 24.9 , then the recommended weight gain range for your pregnancy is 25 to 35 pounds. The red area shows the weight gain recommendation.

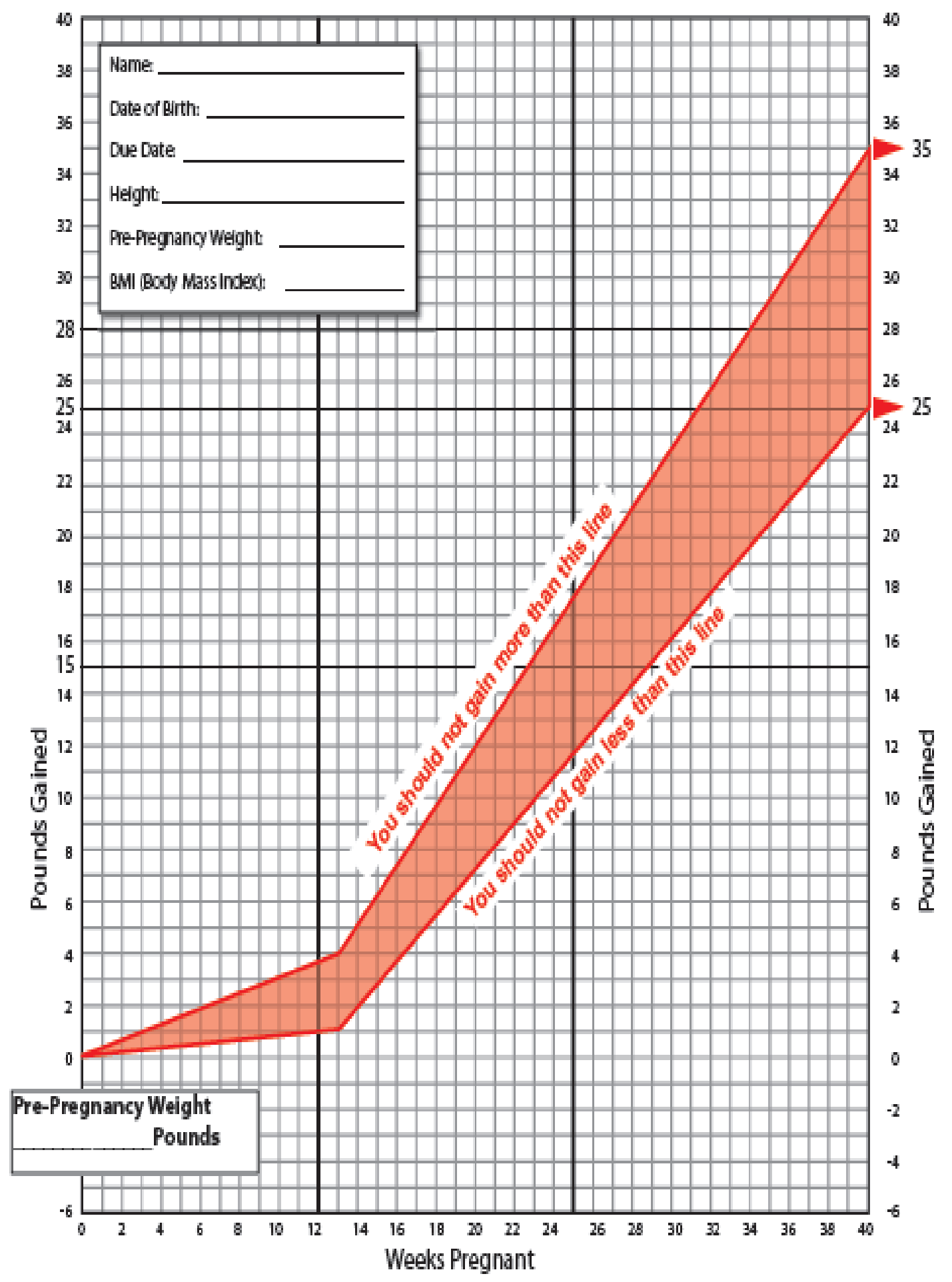




\section{Pregnancy Weight Gain Chart in Pounds}

Pre-pregnancy BMI 25.0-29.9, 15-25 pounds

If your pre-pregnancy BMI is between 25.0 and 29.9 , then the recommended weight gain range for your pregnancy is 15 to 25 pounds. The green area shows the weight gain recommendation.

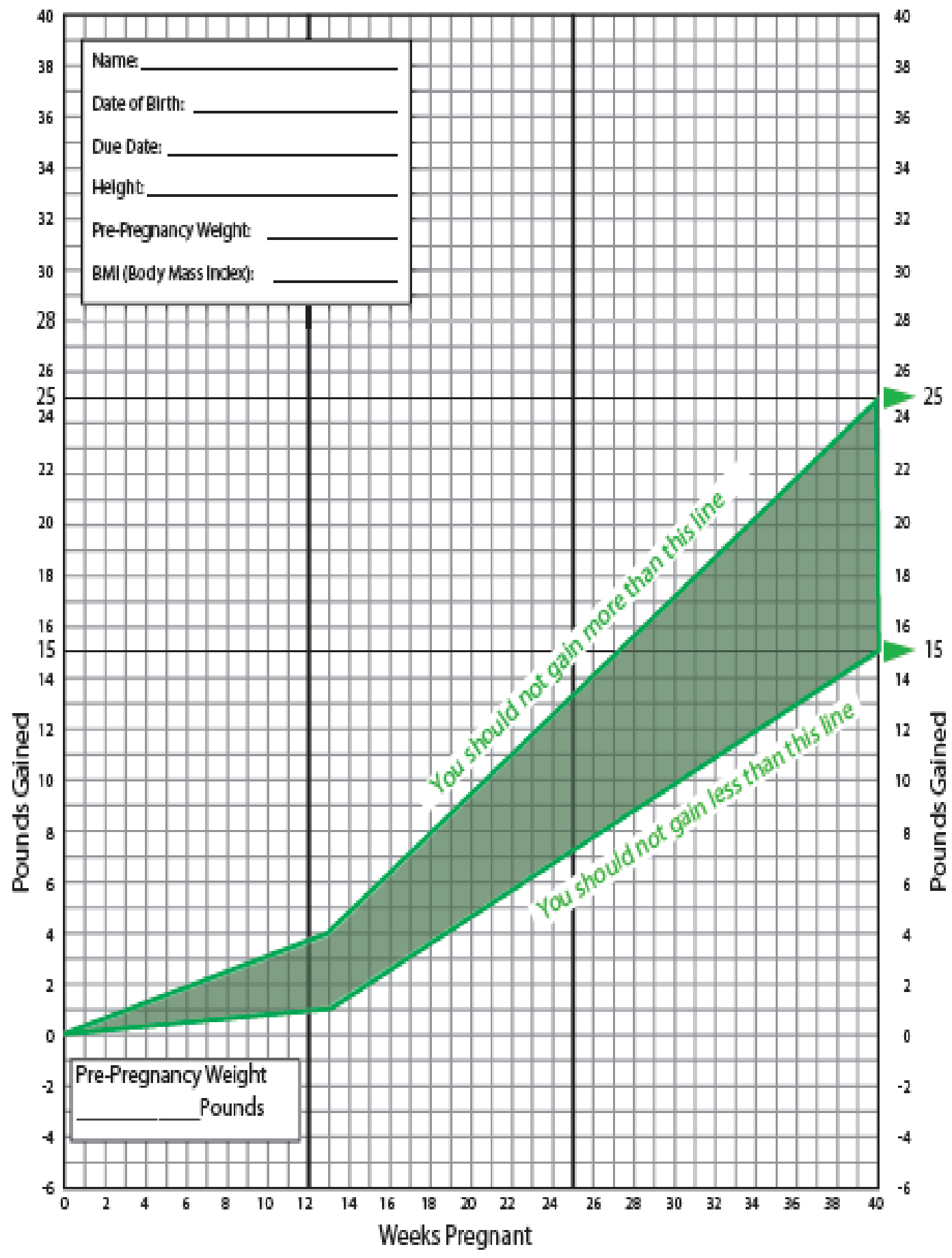




\section{Pregnancy Weight Gain Chart in Pounds}

\section{Pre-pregnancy BMI $\geq 30,11-20$ pounds}

If your pre-pregnancy BMI is 30.0 or greater, then the recommended weight gain range for your

pregnancy is 11 to 20 pounds. The purple area shows the weight gain recommendation.

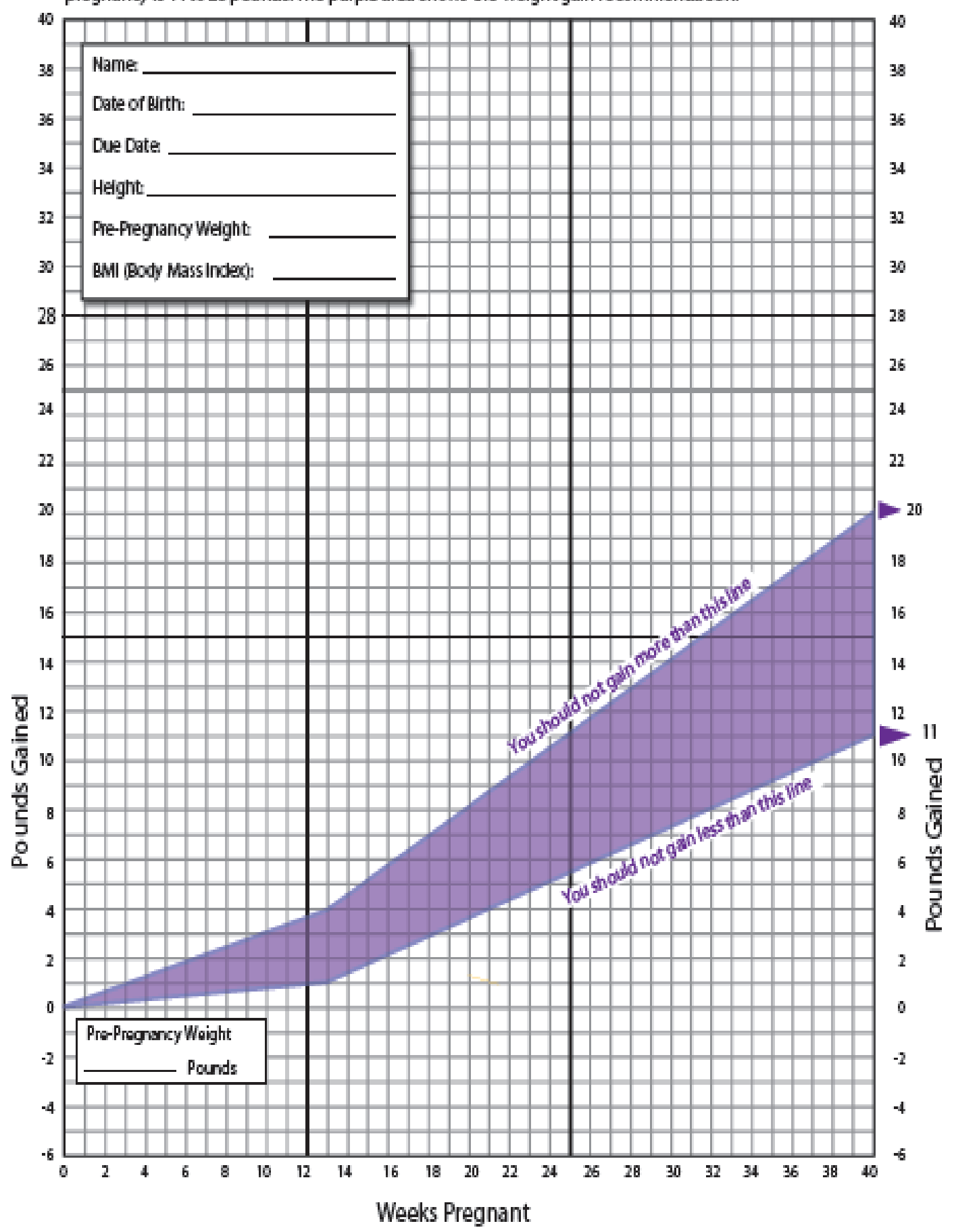




\section{Appendix F}

\section{STATEMENT OF INFORMED CONSENT}

This research study is being conducted by Dr. Rickelle Richards, $\mathrm{PhD}, \mathrm{MPH}, \mathrm{RD}$ and graduate student Tianna Watson from the Department of Nutrition, Dietetics, \& Food Science at Brigham Young University.

You have been asked to take part in a interview and a 2 to 4 month follow-up group interview about the foods you eat during pregnancy. You were invited to take part in this study because you are at least 7-months pregnant, currently receive or are eligible for one or more government food assistant programs (e.g., WIC, Food Stamps), and live in Utah County. We want to learn more about what influences your food choices during pregnancy, how your eating and exercise patterns have changed compared to before you were pregnant, and your thoughts about being healthy during pregnancy. In addition, we would like to know how your eating and exercise patterns have changed after your baby is born. By agreeing to take part in this study, you agree to take part in both the interview during pregnancy and the 2 to 4 month follow-up interview.

Time 1 (Interview during Pregnancy): During the interview you will be asked to share your thoughts and experiences about how you decide what to eat, how your eating habits have changed since becoming pregnant and the factors that influence these changes, and what your thoughts are on food and exercise habits during pregnancy. So we will not miss any of the comments made by those taking part in the study, we will be audio-recording the interviews. Only your first name will be attached to the transcript. You will also be asked to give information about your gender, educational level, the number of children in your household, if you are taking any dietary supplements, and how you feel about your overall health right now. Your height and weight will also be measured. The interview will last about $1 \frac{1 / 2}{2}$ hours.

Time 2 (2 to 4 month Follow-up Interview): Two to four months after your baby is born, you will be asked to take part in a follow-up interview to share your thoughts and experiences about how your eating and exercise habits have changed after you have had your baby, how people around you influence these changes, any health concerns you have after pregnancy, and how you feed your baby. So we will not miss any of the comments made by those taking part in the follow-up, we will also audio-record the interviews. Only your first name will be attached to the transcript. You will also be asked to give information about your gender, educational level, the number of children in your household, if you are taking any dietary supplements, and how you feel about your overall health. Your height and weight will also be measured. The interview will last about $1 \frac{1}{2} 2$ hours.

\section{Benefits}

There are no benefits to you in taking part in this research study. However, results from this study will provide valuable information about how women who are currently receiving or who are eligible for food assistance programs can be better served by these programs.

\section{Risks}

There are minimal risks for participation in this study. The risk in taking part in this study are that we will be asking you personal questions, such as things that influence your eating and exercise habits, during the pregnancy discussion group (Time 1) and on the 2 to 4 month follow-up discussion group (Time 2). 


\section{Compensation}

You will receive \$20 gift card for your time in the pregnancy interview and for having your height and weight measured (Time 1).

You can receive up to an additional \$20 gift card for participating in the 2 to 4 month follow-up interview and having your height and weight measured (Time 2).

\section{Confidentiality}

All information collected (from Time 1 - the pregnancy discussion group and Time 2 - the 2 to 4 month follow-up discussion group) will be kept private, in a locked file cabinet in Dr. Rickelle Richards' office. Only Dr. Rickelle Richards and Tianna Watson will have access to the collected information. The information collected may be published. Your privacy will be protected and will not be identified in anyway. No individual information will be released.

\section{Participation}

Participation in this research study is voluntary and you have the right to withdraw at anytime or refuse to participate entirely without affecting any present or future relations with Brigham Young University or any community public program.

\section{Questions about the Research/Rights as Research Participants}

If you have questions regarding this study as a research participant, you may contact Dr. Rickelle Richards, PhD, MPH, RD at 801-422-6855, rickelle_richards@byu.edu or Tianna Watson at 760-7161274, tiannawatson@rocketmail.com from the Department of Nutrition, Dietetics, \& Food Science at Brigham Young University, S-233 ESC, Provo, UT 84602.

If you have questions or concerns about this research study and would like to talk to someone other than the researchers, please contact Dr. Christopher Dromey, PhD, Chair of the Institutional Review Board for Human Subjects, 133 TLRB, Brigham Young University, Provo, UT 84602 at (801) 422-6461 or e-mail at christopher_dromey@byu.edu.

By signing below, you indicate that you understand the process involved in this study. I have read, understood, and received a copy of the above consent and desire of my own free will to participate in both the pregnancy discussion group (Time 1) and 2 to 4 month follow-up discussion group (Time 2).

Signature:

Date:

Date: 


\section{Appendix G}

\section{Interview Questions - During Pregnancy}

\section{Icebreaker: What is one thing you have never done before but would like to do in your lifetime?}

1) How have your eating habits changed from before your pregnancy to now?

Probes:

a. What or who has influenced you to make changes?

b. What are your perceptions of "eating for two" during pregnancy?

c. How do you think your eating habits will change after you have your baby, if at all?

2) Describe your typical food shopping behaviors.

Probes:

a. How frequently do you go shopping for food? How far do you have to travel to do your food shopping?

b. How do you decide what foods you will buy in the store?

c. How does time influence your shopping behaviors?

d. How do other people (e.g., family, friends) and media influence the foods you buy?

e. How does season influence the foods you buy?

3) How has pregnancy influenced your shopping behaviors? How do you think they will change after pregnancy?

4) For those of you using WIC, what do you think about the foods provided in the WIC packages? Probes:

a. How adequate are the food packages for providing you with enough food to eat during pregnancy?

b. How are the foods you get from WIC used in your household? (For example, are the foods consumed by you, given to your children and/or other family members or friends? Are they discarded or stored for later use?)

c. Are there foods you get from WIC but don't use? If so, what do you do with them?

5) Recently, the WIC Program approved a change to the food packages in which fresh fruits and vegetables will be included on the vouchers. What do you think about this change? 
6) How has pregnancy influenced your cooking habits?

Probes:

a. If you have changed your cooking patterns since being pregnant, how has this affected your food intake? Does smell play a role in your cooking?

b. How does time influence the foods/meals that you cook?

c. For those of you using WIC, how do you cook the food you buy with your WIC vouchers?

7) What advice have you been given about nutrition during pregnancy?

Probes:

a. What advice have you received from your doctor or health care provider? From family and friends? From WIC staff?

b. What are your perceptions about the information given?

8) How have your thoughts/attitudes about health changed since becoming pregnant?

Probes:

a. How does nausea/morning sickness or other health concerns influence your eating patterns during pregnancy?

b. What are some barriers, if any, to eating a healthy diet during pregnancy?

c. For those of you using WIC, how do you feel WIC benefits your health? What are any concerns you have about WIC?

9) How have your exercise habits changed since becoming pregnant? Do you think they will change after pregnancy? If so, tell us more about that.

CLOSING: Summary of what was said - Does this seem to cover all that we've talked about today? Have I missed anything? 


\section{Appendix H}

\section{Interview Questions - After Pregnancy}

\section{Icebreaker Question: If you could have any food right now what would it be?}

1) How have your eating habits changed since pregnancy?

Probes:

a. What has influenced these changes?

b. What are some barriers, if any, to eating a healthy diet now that your baby is born?

c. For those of you who breastfeed your baby, how has your appetite and eating patterns changed?

2) Describe your typical food shopping behaviors now that your baby is born.

Probes:

a. How have your shopping behaviors changed now that your baby is born?

b. How frequently do you go shopping for food? How far do you have to travel to do your food shopping?

c. How do you decide what foods you will buy in the store?

d. How do other people (e.g., family, friends) and media influence what you purchase now that your baby is born?

e. How does time influence your food shopping behaviors?

f. How does season influence the foods you buy?

3) For those of you using WIC, what do you think about the foods provided in the WIC packages now that your baby is born?

Probes:

a. How adequate are the food packages for providing you with enough food to eat?

b. How are the foods you get from WIC used in your household? (For example, are the foods consumed by you, given to your children and/or other family members or friends? Are they discarded or stored for later use?)

c. Are there foods you can get from WIC but don't use? If so, what do you do with them? 
4) How have your cooking habits changed after pregnancy?

Probes:

a. If you have changed your cooking patterns after pregnancy, how has this affected your food intake?

b. How does time influence the foods/meals that you cook?

c. For those of you using WIC, how do you cook the food you buy with your WIC vouchers?

5) What advice have you been given regarding nutrition and losing weight after pregnancy?

Probes:

a. What advice have you received from your doctor or health care provider? From family and friends? From WIC staff?

b. What are your perceptions about the information given?

6) How many of you are concerned about losing postpartum weight? Can you tell us more about that?

Probes:

a. If yes, how do you plan to lose the weight associated with your pregnancy?

b. If yes, what are some things you would like to do that you aren't doing right now to lose weight?

7) How have your thoughts/attitudes about health changed now that your baby is born?

Probes:

a. Have you experienced postpartum blues? Has this affected your eating habits?

b. For those of you using WIC, how do you feel WIC benefits your health now that your baby is born? What are any concerns you have about WIC?

8) How have your exercise habits changed after pregnancy?

CLOSING: Summary of what was said - Does this seem to cover all that we've talked about today? Have I missed anything? 


\section{Appendix I}

\section{Demographics Questionnaire DURING PREGNANCY}

Please mark an " $\mathrm{x}$ " in the box with the best choice or fill in the blank.

1. Age: Years

2. Race:

${ }^{1} \square$ Caucasian (White)
${ }^{2} \square$ Hispanic
${ }^{3} \square$ Asian
${ }^{4} \square$ American Indian
${ }^{5} \square$ Other (specify):

3. Marital status:

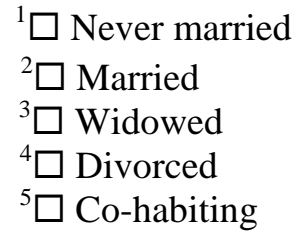

4. What was your approximate family income from all sources, before taxes, in 2008?

${ }^{1} \square$ Less than $\$ 5,000$

${ }^{2} \square \$ 5,001-\$ 9,999$

${ }^{3} \square$ \$10,000-\$19,999

${ }^{4} \square \$ 20,000-\$ 39,999$

${ }^{5} \square$ Greater than $\$ 40,000$

5. Highest Level of Education Completed:

${ }^{1} \square 8^{\text {th }}$ grade or less

${ }^{2} \square$ Some high school

${ }^{3} \square$ High school graduate / GED or equivalent

${ }^{4} \square$ Some college

${ }^{5} \square$ Completed college

${ }^{6} \square$ Completed graduate / Professional school

6. Which of the following best explains your employment right now?

${ }^{1} \square$ Working in a paid job (30 or more hours per week)

${ }^{2} \square$ Working in a paid job (8-29 hours per week)

${ }^{3} \square$ Working in a paid job (less than 8 hours per week)

${ }^{4} \square$ Self-employed

${ }^{5} \square$ Not in paid employment / Looking after house or home

${ }^{6} \square$ Full-time student in school and not working in a paid job

${ }^{7} \square$ Unemployed / Seeking employment

${ }^{8} \square$ Retired from employment

7. Total number of adults (over 18 years old) in household:

8. Number of children (under the age of 18) in household:

9. Do you own a house, condo, or townhouse (includes making mortgage payments)?

\footnotetext{
${ }^{1} \square$ No -----> If no, please continue.

${ }^{2} \square$ Yes ----> If yes, skip to Question 11.
} 
10. Do you rent a house, apartment, or townhouse?

${ }^{1} \square$ No -----> If no, please continue.

${ }^{2} \square$ Yes ----> If yes, please continue.

11. Are you using WIC right now?

${ }^{1} \square$ No ----> If no, skip to Question 15.

${ }^{2} \square$ Yes ----> If yes, please continue.

12. How long have you been with the WIC program?

${ }^{1} \square$ Less than one month

${ }^{2} \square$ 1-3 months

${ }^{3} \square$ 4-6 months

${ }^{4} \square$ 7-9 months

${ }^{5} \square$ 10-12 months

${ }^{6} \square$ More than 12 months

13. Do you usually get the following foods at the store from your WIC vouchers for your household?

\begin{tabular}{|c|c|c|c|}
\hline 13a. & Eggs & ${ }^{1} \square$ No & ${ }^{2} \square$ Yes \\
\hline 3b. & Cereal & ${ }^{1} \square$ No & ${ }^{2} \square$ Yes \\
\hline 3c. & Whole Grain Cereal & ${ }^{1} \square$ No & ${ }^{2} \square$ Yes \\
\hline 3d. & Whole Grain Bread & ${ }^{1} \square$ No & ${ }^{2} \square$ Yes \\
\hline 13e. & Fruit Juice & ${ }^{1} \square$ No & ${ }^{2} \square$ Yes \\
\hline $3 f$. & Fresh Fruit & ${ }^{1} \square$ No & ${ }^{2} \square Y$ \\
\hline 3g. & Vegetable Juice & ${ }^{1} \square$ No & ${ }^{2} \square Y$ \\
\hline $13 \mathrm{~h}$. & Fresh Vegetables & ${ }^{1} \square$ No & ${ }^{2} \square$ Yes \\
\hline 13i. & Whole Milk & ${ }^{1} \square$ No & ${ }^{2} \square$ Yes \\
\hline 13j. & 2\% Milk & ${ }^{1} \square$ No & ${ }^{2} \square$ Yes \\
\hline $13 \mathrm{k}$. & 1\% Milk & ${ }^{1} \square$ No & ${ }^{2} \square$ Yes \\
\hline 131. & Skim Milk & ${ }^{1} \square$ No & ${ }^{2} \square$ Yes \\
\hline $13 \mathrm{~m}$. & Soy Milk & ${ }^{1} \square$ No & ${ }^{2} \square$ Yes \\
\hline 13n. & Cheese & ${ }^{1} \square$ No & ${ }^{2} \square \mathrm{Ye}$ \\
\hline 130. & Dried Beans & ${ }^{1} \square$ No & ${ }^{2} \square$ Yes \\
\hline 13p & Peanut Butter & ${ }^{1} \square$ No & ${ }^{2} \square \mathrm{Ye}$ \\
\hline & Canned Tuna, & & \\
\hline & Salmon, Sardines & ${ }^{1} \square$ No & ${ }^{2} \square$ Yes \\
\hline $\mathrm{r}$ & Tofu & ${ }^{1} \square$ No & ${ }^{2} \square \mathrm{Ye}$ \\
\hline
\end{tabular}


14. Which of these foods do you usually eat yourself (not including other members in your household)?

\begin{tabular}{|c|c|c|c|}
\hline $14 a$. & Eggs & ${ }^{1} \square$ No & ${ }^{2} \square$ Yes \\
\hline 14b. & Cereal & ${ }^{1} \square$ No & ${ }^{2} \square$ Yes \\
\hline . & Whole Grain Cereal & ${ }^{1} \square$ No & ${ }^{2} \square$ Yes \\
\hline td. & Whole Grain Bread & ${ }^{1} \square$ No & ${ }^{2} \square$ Yes \\
\hline 4e. & Fruit Juice & ${ }^{1} \square$ No & ${ }^{2} \square$ Yes \\
\hline $14 \mathrm{f}$. & Fresh Fruit & ${ }^{1} \square$ No & ${ }^{2} \square$ Yes \\
\hline tg. & Vegetable Juice & ${ }^{1} \square$ No & ${ }^{2} \square$ Yes \\
\hline th. & Fresh Vegetables & ${ }^{1} \square$ No & ${ }^{2} \square$ Yes \\
\hline 4i. & Whole Milk & ${ }^{1} \square$ No & ${ }^{2} \square$ Yes \\
\hline 14j. & 2\% Milk & ${ }^{1} \square$ No & ${ }^{2} \square$ Yes \\
\hline $14 \mathrm{k}$. & 1\% Milk & ${ }^{1} \square$ No & ${ }^{2} \square$ Yes \\
\hline 41. & Skim Milk & ${ }^{1} \square$ No & ${ }^{2} \square$ Yes \\
\hline $4 \mathrm{~m}$. & Soy Milk & ${ }^{1} \square$ No & ${ }^{2} \square$ Yes \\
\hline $4 \mathrm{n}$. & Cheese & ${ }^{1} \square$ No & ${ }^{2} \square$ Yes \\
\hline 40. & Dried Beans & ${ }^{1} \square$ No & ${ }^{2} \square$ Yes \\
\hline tp. & Peanut Butter & ${ }^{1} \square$ No & ${ }^{2} \square$ Yes \\
\hline & $\begin{array}{l}\text { Canned Tuna, } \\
\text { Salmon, Sardines }\end{array}$ & ${ }^{1} \square$ No & ${ }^{2} \square$ Yes \\
\hline Ir & Tofu & ${ }^{1} \square$ No & ${ }^{2} \square$ Yes \\
\hline
\end{tabular}

15. Are you using SNAP (Food Stamps) right now?

${ }^{1} \square$ No -----> If no, skip to question 18.

${ }^{2} \square$ Yes ----> If yes, please continue.

16. How long have you been using SNAP (Food Stamps)?

${ }^{1} \square$ Less than one month

${ }^{2} \square 1-3$ months

${ }^{3} \square$ 4-6 months

${ }^{4} \square$ 7-9 months

${ }^{5} \square$ 10-12 months

${ }^{6} \square$ More than 12 months

17. How much SNAP (Food Stamp) money do you get each month? \$

EACH MONTH 
18. How do you usually get to where you shop for food?

${ }^{1} \square$ Drive own car

${ }^{2} \square$ Ride with a friend or family member

${ }^{3} \square$ Take bus

${ }^{4} \square$ Walk

${ }^{5} \square$ Ride bike

${ }^{6} \square$ Other (specify):

19. About how far do you live from where you usually shop for food?

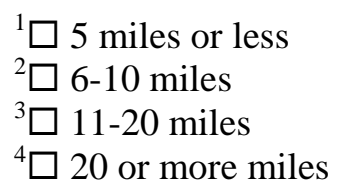

Questions 20-47 are about your current pregnancy, things before your pregnancy, and your plans after pregnancy. Please fill in the blank or mark an " $x$ " in the box with the best choice.

20. How long have you been pregnant?

WEEKS

21. Are you getting prenatal care right now? $\quad{ }^{1} \square$ No $\quad{ }^{2} \square$ Yes

22. What is your baby's due date? Month:

Day:

23. How much did you weigh before pregnancy? Pounds

24. How tall are you? Feet Inches

25. How many pregnancies (besides your current one) have you had? .

26. How many live births have you had?

27. In general, you would say your health is:

${ }^{1} \square$ Excellent
${ }^{2} \square$ Very good
${ }^{3} \square$ Good
${ }^{4} \square$ Fair
${ }^{5} \square$ Poor

28. Do you have diabetes right now?

${ }^{1} \square$ No----> If no, skip to Question 29.

${ }^{2} \square$ Yes ----> If yes, please continue.

28a. Did you have diabetes before you were pregnant?

${ }^{1} \square$ No

${ }^{2} \square$ Yes

29. Have you developed high blood pressure during your current pregnancy? ${ }^{1} \square$ No $\quad{ }^{2} \square$ Yes

30. Did you have high blood pressure before your current pregnancy? ${ }^{1} \square$ No ${ }^{2} \square$ Yes 
31. Have you had swelling in your arms, hands, legs, ankles or feet during your current pregnancy?

${ }^{1} \square$ No ${ }^{2} \square$ Yes

32. Have you had any other health concerns during your current pregnancy? ${ }^{1} \square$ No ${ }^{2} \square$ Yes --> If yes, please explain:

33. How would you describe your weight gain during your pregnancy so far?

Weight too much

Weight too little

$\square$ Weight the right amount

34. Are you taking a dietary supplement right now (like a prenatal vitamin or other vitamin/mineral supplement)?

${ }^{1} \square$ No ---> If no, skip to question 35.

${ }^{2} \square$ Yes ---> If yes, please continue.

34a. Who told you about the dietary supplement you are taking right now?

${ }^{1} \square$ Doctor

${ }^{2} \square$ A family member/friend

${ }^{3} \square$ WIC

${ }^{4} \square$ Found on my own

${ }^{5} \square$ Other (specify):

35. Are you taking any prescribed medication(s) (this means any drugs given to you by your doctor) right now?

${ }^{1} \square$ No ---> If no, skip to question 37.

${ }^{2} \square$ Yes ---> If yes, please continue.

35a. What is the name of the medication(s) you are taking right now?

\section{For Questions 36-42:}

Exercise is anything you do for 30 minutes that moves your body, like walking, jogging, playing sports, dancing, or yoga/pilates.

Diet/Dieting is eating less than you usually would or eating different foods than normal to lose weight.

36. Did you exercise before your current pregnancy?

${ }^{1} \square$ No ---> If no, skip to question 37.

${ }^{2} \square$ Yes ---> If yes, please continue.

36a. How many times did you exercise each week before pregnancy? Times each week

37. Do you exercise now that you are pregnant?

${ }^{1} \square$ No ---> If no, skip to question 38.

${ }^{2} \square$ Yes ---> If yes, please continue.

37a. How many times do you exercise each week now that you are pregnant?

Times each week 
38. Do you plan to exercise 2 to 4 months after your baby is born?

${ }^{1} \square$ No ---> If no, skip to question 39.

${ }^{2} \square$ Yes ---> If yes, please continue.

38a. How many times do you plan to exercise each week after your baby is born?

Times each week

39. Did you follow any of these diet plans before your current pregnancy?

\begin{tabular}{lcc} 
Low carb, high protein diet (like Atkin’s diet, The Zone diet, etc.) & ${ }^{1} \square$ No & ${ }^{2} \square$ Yes \\
Raw Foods Diet & ${ }^{1} \square$ No & ${ }^{2} \square$ Yes \\
Mediterranean Diet & ${ }^{1} \square$ No & ${ }^{2} \square$ Yes \\
Slim Fast Diet & ${ }^{1} \square$ No & ${ }^{2} \square$ Yes \\
Weight Watchers & ${ }^{1} \square$ No & ${ }^{2} \square$ Yes \\
Cleansing Diet (like Master Cleanse Diet, Isagenix, etc.) & ${ }^{1} \square$ No & ${ }^{2} \square$ Yes \\
Jenny Craig & ${ }^{1} \square$ No & ${ }^{2} \square$ Yes \\
Eating less than normal to lose weight & ${ }^{1} \square$ No & ${ }^{2} \square$ Yes \\
Other (specify): & \\
\hline
\end{tabular}

40. Are you following any of these diet plans during your current pregnancy?

Low carb, high protein diet (like Atkin's diet, The Zone diet, etc.)

Raw Foods Diet

${ }^{1} \square$ No

${ }^{2} \square$ Yes

Mediterranean Diet

${ }^{1} \square$ No

${ }^{2} \square$ Yes

Slim Fast Diet

${ }^{1} \square$ No

${ }^{2} \square$ Yes

Weight Watchers

${ }^{1} \square$ No

${ }^{2} \square$ Yes

Cleansing Diet (like Master Cleanse Diet, Isagenix, etc.)

${ }^{1} \square$ No

${ }^{2} \square$ Yes

Jenny Craig

Eating less than normal to lose weight

${ }^{1} \square$ No $\quad{ }^{2} \square$ Yes

Other (specify):

41. Do you think you will follow any of these diet plan(s) after your baby is born?

\begin{tabular}{|c|c|c|}
\hline Low carb, high protein diet (like Atkin's diet, The Zone diet, etc.) & ${ }^{1} \square$ No & ${ }^{2} \square$ Yes \\
\hline Raw Foods Diet & ${ }^{1} \square$ No & ${ }^{2} \square$ Yes \\
\hline Mediterranean Diet & ${ }^{1} \square$ No & ${ }^{2} \square$ Yes \\
\hline Slim Fast Diet & ${ }^{1} \square$ No & ${ }^{2} \square$ Yes \\
\hline Weight Watchers & ${ }^{1} \square$ No & ${ }^{2} \square$ Yes \\
\hline Cleansing Diet (like Master Cleanse Diet, Isagenix, etc.) & ${ }^{1} \square$ No & ${ }^{2} \square$ Yes \\
\hline Jenny Craig & ${ }^{1} \square$ No & ${ }^{2} \square$ Yes \\
\hline $\begin{array}{l}\text { Eating less than normal to lose weight } \\
\text { Other (specify): }\end{array}$ & ${ }^{1} \square$ No & ${ }^{2} \square$ Yes \\
\hline
\end{tabular}


42. Did you smoke cigarettes before your current pregnancy?

${ }^{1} \square$ No ---> If no, skip to question 44.

${ }^{2} \square$ Yes ---> If yes, please continue.

42a. How many cigarettes did you smoke each day before your current pregnancy? Cigarettes

43. Do you smoke cigarettes now that you are pregnant?

${ }^{1} \square$ No ---> If no, skip to question 45.

${ }^{2} \square$ Yes ---> If yes, please continue.

43a. How many cigarettes do you smoke each day now that you are pregnant? Cigarettes

44. Do you plan to smoke cigarettes after your baby is born?

${ }^{1} \square$ No ---> If no, skip to question 46.

${ }^{2} \square$ Yes ---> If yes, please continue.

44a. How many cigarettes do you plan to smoke each day after your baby is born? Cigarettes

45. Did you drink alcohol before your current pregnancy?

${ }^{1} \square$ No ---> If no, skip to question 47.

${ }^{2} \square$ Yes ---> If yes, please continue.

45a. How much alcohol did you drink each week before your current pregnancy?

Ounces of beer/wine Ounces of liquor/distilled spirits

46. Do you drink alcohol now that you are pregnant?

${ }^{1} \square$ No ---> If no, skip to question 48.

${ }^{2} \square$ Yes ---> If yes, please continue.

46a. How much alcohol do you drink each week now that you are pregnant?

Ounces of beer/wine

Ounces of liquor/distilled spirits

47. Do you plan to drink alcohol after your baby is born?

${ }^{1} \square$ No ---> If no, you have reached the end of the questions. Please give this to one of the researchers.

${ }^{2} \square$ Yes ---> If yes, please continue.

47a. How much alcohol do you plan to drink each week after your baby is born?

Ounces of beer/wine

Ounces of liquor/distilled spirits

Thank you! Please give this survey to one of the researchers. 


\section{Household Survey - Food Questions about the Last 30 Days}

For these statements, please mark whether the statement was often true, sometimes true, or never true for (you/your household) in the last 30 days.

1) In the last 30 days, I/we worried whether my/our food would run out before I/we got money to buy more.
[ ] Often true
[ ] Sometimes true
[ ] Never true
[ ] Don’t Know

2) In the last 30 days, the food that I/we bought just didn't last, and I/we didn't have money to get more.

[ ] Often true

[ ] Sometimes true

[ ] Never true

[ ] Don't know

3) In the last $\mathbf{3 0}$ days, I/we couldn't afford to eat balanced meals.
[ ] Often true
[ ] Sometimes true
[ ] Never true
[ ] Don't know

4) In the last 30 days, did you or other adults in your household ever cut the size of your meals or skip meals because there wasn't enough money for food?

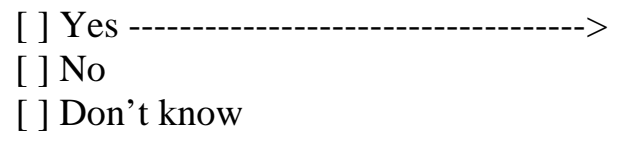

If yes, in the last 30 days, how many days did this happen?

[ ] Don’t know

5) In the last $\mathbf{3 0}$ days, did you ever eat less than you felt you should because there wasn't enough money for food?
[] Yes
[] No
[ ] Don't know

6) In the last 30 days, were you every hungry but didn't eat because there wasn't enough money for food?
[] Yes
[] No
[ ] Don't know 
7) In the last $\mathbf{3 0}$ days, did you lose weight because there wasn't enough money for food?
[] Yes
[] No
[ ] Don’t know

8) In the last 30 days, did you/you or other adults in your household ever not eat for a whole day because there wasn't enough money for food?

\begin{tabular}{|c|c|}
\hline$--->$ & $\begin{array}{l}\text { If yes, in the last } 30 \text { days, how many } \\
\text { days did this happen? }\end{array}$ \\
\hline $\begin{array}{l}\text { No } \\
\text { Don't know }\end{array}$ & [ ] Don't know \\
\hline
\end{tabular}

The next questions are about children living in your household under 18 years old.

9) In the last $\mathbf{3 0}$ days, I/we relied on only a few kinds of low-cost food to feed my/our child/the children because I was/we were running out of money to buy food.

[ ] Often true

[ ] Sometimes true

[ ] Never true

[ ] Don’t know

10) In the last $\mathbf{3 0}$ days, I/We couldn’t feed my/our child/the children a balanced meal, because I/we couldn't afford that.
[ ] Often true
[ ] Sometimes true
[ ] Never true
[] Don't know

11) In the last 30 days, my/our child was (or the children were) not eating enough because I/we just couldn't afford enough food.
[ ] Often true
[ ] Sometimes true
[] Never true
[ ] Don’t know

12) In the last $\mathbf{3 0}$ days, did you ever cut the size of your child's/any of the children's meals because there wasn't enough money for food?
[] Yes
[] No
[ ] Don't know

13) In the last 30 days, did your child/children ever skip meals because there wasn't enough money for food?

[] Yes

[] No

[ ] Don’t know
If yes, in the last 30 days, how many days did this happen?

[ ] Don’t know 
14) In the last 30 days, was your child/were the children ever hungry but you just couldn't afford more food?

[ ] Yes

[] No

[ ] Don't know

15) In the last 30 days, did your child/any of the children ever not eat for a whole day because there wasn't enough money for food?

[] Yes

[] No

[ ] Don’t know

Coding Responses and Assessing Household Food Security Status:

Responses of "yes," "often," "sometimes," "almost every month," and "some months but not every month" on the "Last 12 months" survey are coded as affirmative. The sum of affirmative responses to a specified set of items is referred to as the household's raw score on the scale comprising those items.

o For households with one or more children:

- Raw score zero-High food security

- Raw score 1-2-Marginal food security

- Raw score 3-7-Low food security

- Raw score 8-18-Very low food security

o For households with no child present:

- Raw score zero-High food security

- Raw score 1-2-Marginal food security

- Raw score 3-5-Low food security

- Raw score 6-10-Very low food security

Households with high or marginal food security are classified as food secure. Those with low or very low food security are classified as food insecure.

30-Day Reference Period: The questionnaire items may be modified to a 30-day reference period by changing the "last 12-month" references to "last 30 days." In this case, items AD1a, AD5a, and CH5a must be changed to read as follows:

AD1a/AD5a/CH5a [IF YES ABOVE, ASK] In the last 30 days, how many days did this happen?

[ ] DK days

According to Mark Nord (Economic Research Service, USDA, personal communication), when a participant responds that these events on the "last 30 days" survey occur 3 or more days, this is considered an affirmative response. 


\section{Appendix K}

\section{Demographics Questionnaire AFTER PREGNANCY}

Please mark an " $\mathrm{x}$ " in the box with the best choice or fill in the blank.

1. Age: Years

2. Race:

${ }^{1} \square$ Caucasian (White)
${ }^{2} \square$ Hispanic
${ }^{3} \square$ Asian
${ }^{4} \square$ American Indian
${ }^{5} \square$ Other (specify):

3. Marital status:

${ }^{1} \square$ Never married
${ }^{2} \square$ Married
${ }^{3} \square$ Widowed
${ }^{4} \square$ Divorced
${ }^{5} \square$ Co-habiting

4. What was your approximate family income from all sources, before taxes, in 2008 ?

${ }^{1} \square$ Less than $\$ 5,000$
${ }^{2} \square$ \$5,001- $\$ 9,999$
${ }^{3} \square \$ 10,000-\$ 19,999$
${ }^{4} \square$ \$20,000-\$39,999
${ }^{5} \square$ Greater than $\$ 40,000$

5. Highest Level of Education Completed:

${ }^{1} \square 8^{\text {th }}$ grade or less

${ }^{2} \square$ Some high school

${ }^{3} \square$ High school graduate / GED or equivalent

${ }^{4} \square$ Some college

${ }^{5} \square$ Completed college

${ }^{6} \square$ Completed graduate / Professional school

6. Which of the following best explains your employment right now?

\footnotetext{
${ }^{1} \square$ Working in a paid job (30 or more hours per week)

${ }^{2} \square$ Working in a paid job (8-29 hours per week)

${ }^{3} \square$ Working in a paid job (less than 8 hours per week)

${ }^{4} \square$ Self-employed

${ }^{5} \square$ Not in paid employment / Looking after house or home

${ }^{6} \square$ Full-time student in school and not working in a paid job

${ }^{7} \square$ Unemployed / Seeking employment

${ }^{8} \square$ Retired from employment
}

7. Total number of adults (over 18 years old) in household:

8. Number of children (under the age of 18) in household:

9. Do you own a house, condo, or townhouse (includes making mortgage payments)?

\footnotetext{
${ }^{1} \square$ No -----> If no, please continue.

${ }^{2} \square$ Yes ----> If yes, skip to Question 11.
} 
10. Do you rent a house, apartment, or townhouse?

${ }^{1} \square$ No -----> If no, please continue.

${ }^{2} \square$ Yes ----> If yes, please continue.

11. Are you using WIC right now?

${ }^{1} \square$ No ----> If no, skip to Question 15.

${ }^{2} \square$ Yes ----> If yes, please continue.

12. How long have you been with the WIC program?

${ }^{1} \square$ Less than one month

${ }^{2} \square$ 1-3 months

${ }^{3} \square$ 4-6 months

${ }^{4} \square$ 7-9 months

${ }^{5} \square$ 10-12 months

${ }^{6} \square$ More than 12 months

13. Do you usually get the following foods at the store from your WIC vouchers for your household?

$\begin{array}{llll}\text { 13a. Eggs } & { }^{1} \square \text { No } & { }^{2} \square \text { Yes } \\ \text { 13b. Cereal } & { }^{1} \square \text { No } & { }^{2} \square \text { Yes } \\ \text { 13c. } \text { Whole Grain Cereal } & { }^{1} \square \text { No } & { }^{2} \square \text { Yes } \\ \text { 13d. Whole Grain Bread } & { }^{1} \square \text { No } & { }^{2} \square \text { Yes } \\ \text { 13e. } \text { Fruit Juice } & { }^{1} \square \text { No } & { }^{2} \square \text { Yes } \\ \text { 13f. } \text { Fresh Fruit } & { }^{1} \square \text { No } & { }^{2} \square \text { Yes } \\ \text { 13g. } \text { Vegetable Juice } & { }^{1} \square \text { No } & { }^{2} \square \text { Yes } \\ \text { 13h. } \text { Fresh Vegetables } & { }^{1} \square \text { No } & { }^{2} \square \text { Yes } \\ \text { 13i. } \text { Whole Milk } & { }^{1} \square \text { No } & { }^{2} \square \text { Yes } \\ \text { 13j. } \text { 2\% Milk } & { }^{1} \square \text { No } & { }^{2} \square \text { Yes } \\ \text { 13k. } \text { 1\% Milk } & { }^{1} \square \text { No } & { }^{2} \square \text { Yes } \\ \text { 13l. Skim Milk } & { }^{1} \square \text { No } & { }^{2} \square \text { Yes } \\ \text { 13m. Soy Milk } & { }^{1} \square \text { No } & { }^{2} \square \text { Yes } \\ \text { 13n. Cheese } & { }^{1} \square \text { No } & { }^{2} \square \text { Yes } \\ \text { 13o. Dried Beans } & { }^{1} \square \text { No } & { }^{2} \square \text { Yes } \\ \text { 13p. Peanut Butter } & { }^{1} \square \text { No } & { }^{2} \square \text { Yes } \\ \text { 13q. Canned Tuna, } & & \\ & \text { Salmon, Sardines } & { }^{1} \square \text { No } & { }^{2} \square \text { Yes } \\ \text { 13r. Tofu } & { }^{1} \square \text { No } & { }^{2} \square \text { Yes }\end{array}$


14. Which of these foods do you usually eat yourself (not including other members in your household)?

$\begin{array}{llll}\text { 14a. Eggs } & { }^{1} \square \text { No } & { }^{2} \square \text { Yes } \\ \text { 14b. Cereal } & { }^{1} \square \text { No } & { }^{2} \square \text { Yes } \\ \text { 14c. Whole Grain Cereal } & { }^{1} \square \text { No } & { }^{2} \square \text { Yes } \\ \text { 14d. Whole Grain Bread } & { }^{1} \square \text { No } & { }^{2} \square \text { Yes } \\ \text { 14e. Fruit Juice } & { }^{1} \square \text { No } & { }^{2} \square \text { Yes } \\ \text { 14f. Fresh Fruit } & { }^{1} \square \text { No } & { }^{2} \square \text { Yes } \\ \text { 14g. Vegetable Juice } & { }^{1} \square \text { No } & { }^{2} \square \text { Yes } \\ \text { 14h. } \text { Fresh Vegetables } & { }^{1} \square \text { No } & { }^{2} \square \text { Yes } \\ \text { 14i. } \text { Whole Milk } & { }^{1} \square \text { No } & { }^{2} \square \text { Yes } \\ \text { 14j. } \text { 2\% Milk } & { }^{1} \square \text { No } & { }^{2} \square \text { Yes } \\ \text { 14k. } \text { 1\% Milk } & { }^{1} \square \text { No } & { }^{2} \square \text { Yes } \\ \text { 14l. Skim Milk } & { }^{1} \square \text { No } & { }^{2} \square \text { Yes } \\ \text { 14m. Soy Milk } & { }^{1} \square \text { No } & { }^{2} \square \text { Yes } \\ \text { 14n. Cheese } & { }^{1} \square \text { No } & { }^{2} \square \text { Yes } \\ \text { 14o. Dried Beans } & { }^{1} \square \text { No } & { }^{2} \square \text { Yes } \\ \text { 14p. Peanut Butter } & { }^{1} \square \text { No } & { }^{2} \square \text { Yes } \\ \text { 14q. Canned Tuna, } & & \\ & \text { Salmon, Sardines } & { }^{1} \square \text { No } & { }^{2} \square \text { Yes } \\ \text { 14r. Tofu } & { }^{1} \square \text { No } & { }^{2} \square \text { Yes }\end{array}$

15. Are you using SNAP (Food Stamps) right now?

${ }^{1} \square$ No -----> If no, skip to question 18.

${ }^{2} \square$ Yes ----> If yes, please continue.

16. How long have you been using SNAP (Food Stamps)?

${ }^{1} \square$ Less than one month

${ }^{2} \square$ 1-3 months

${ }^{3} \square$ 4-6 months

${ }^{4} \square$ 7-9 months

${ }^{5} \square$ 10-12 months

${ }^{6} \square$ More than 12 months

17. How much SNAP (Food Stamp) money do you get each month? \$ each month 
18. How do you usually get to where you shop for food?

${ }^{1} \square$ Drive own car

${ }^{2} \square$ Ride with a friend or family member

${ }^{3} \square$ Take bus

${ }^{4} \square$ Walk

${ }^{5} \square$ Ride bike

${ }^{6} \square$ Other (specify):

19. About how far do you live from where you usually shop for food?

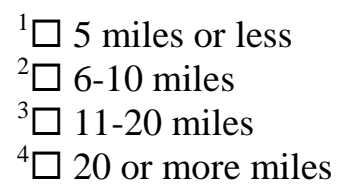

Questions 20-27 are about your most recent pregnancy and now that your baby is born. Please mark an " $x$ " in the box with the best choice or fill in the blank.

20. How much total weight did you gain during your most recent pregnancy? Pounds

21. How would you describe your weight right now?

${ }^{1} \square$ Weight too much

${ }^{2} \square$ Weight too little

${ }^{3} \square$ Weight the right amount

22. Are you taking a dietary supplement right now (like a vitamin and/or mineral supplement)?

${ }^{1} \square$ No ---> If no, skip to question 23.

${ }^{2} \square$ Yes ---> If yes, please continue.

22a. Who told you about the dietary supplement you are taking right now?

${ }^{1} \square$ Doctor

${ }^{2} \square$ A family member/friend

${ }^{3} \square$ WIC

${ }^{4} \square$ Found on my own

${ }^{5} \square$ Other (specify):

23. In general, you would say your health right now is:

${ }^{1} \square$ Excellent

${ }^{2} \square$ Very good

${ }^{3} \square$ Good

${ }^{4} \square$ Fair

${ }^{5} \square$ Poor 


\section{For Questions 24-28:}

Exercising is anything you do for 30 minutes that moves your body, like walking, jogging, playing sports, dancing, or yoga/pilates.

Diet/Dieting is eating less than you usually would or eating different foods than normal to lose weight

24. Do you exercise right now?

${ }^{1} \square$ No ---> If no, skip to question 26.

Yes ---> If yes, please continue.

24a. How many times do you exercise each week now that your baby is born?

Times each week

25. Are you following any of these diet plans right now?

Low carb, high protein diet (like Atkin’s diet, The Zone diet, etc.) ${ }^{1} \square$ No $\quad{ }^{2} \square$ Yes

Raw Foods Diet

${ }^{1} \square$ No $\quad{ }^{2} \square$ Yes

Mediterranean Diet

${ }^{1} \square$ No

Slim Fast Diet

Weight Watchers

${ }^{1} \square$ No

${ }^{2} \square$ Yes

Cleansing Diet (like Master Cleanse Diet, Isagenix, etc.)

Jenny Craig

Eating less than normal to lose weight

${ }^{1} \square$ No

Other (specify):

26. Do you smoke cigarettes now that your baby is born?

${ }^{1} \square$ No ---> If no, skip to question 27.

${ }^{2} \square$ Yes ---> If yes, please continue.

26a. How many cigarettes do you smoke each day now that your baby is born? Cigarettes

27. Do you drink alcohol now that your baby is born?

${ }^{1} \square$ No ---> If no, skip to question 28.

${ }^{2} \square$ Yes ---> If yes, please continue.

27a. How much alcohol do you drink each week now that your baby is born? Ounces of beer/wine Ounces of liquor/distilled spirits 
Questions 28-32 are about your baby that was recently born.

28. When was your baby born? Month:

Day:

29. How much did your baby weigh? Pounds Ounces

30. What was your baby's length at birth? Inches

31. Did you have more than one baby?

${ }^{1} \square$ NO ---> If no, skip to question 32.

${ }^{2} \square$ YES ---> If yes, please continue.

31a. How many babies were born alive? Live births

32. Which of these foods and/or drinks do you feed your baby?
32a. Breast Milk
${ }^{1} \square$ No $\quad{ }^{2} \square$ Yes
32b. Baby Formula
${ }^{1} \square$ No $\quad{ }^{2} \square$ Yes
32c. Cow's Milk (Whole, 2\%, 1\%, OR Skim)
${ }^{1} \square$ No $\quad{ }^{2} \square$ Yes
32d. Soy Milk
${ }^{1} \square$ No $\quad{ }^{2} \square$ Yes
32e. Water
${ }^{1} \square$ No $\quad{ }^{2} \square$ Yes
32f. Juice
${ }^{1} \square$ No $\quad{ }^{2} \square$ Yes
32g. Soda/Soft Drinks
${ }^{1} \square$ No $\quad{ }^{2} \square$ Yes
32h. Baby Cereal (Like Rice Cereal)
${ }^{1} \square$ No $\quad{ }^{2} \square$ Yes
32i. Baby Foods (Like Pureed Fruits, Vegetables, etc.)
${ }^{1} \square$ No $\quad{ }^{2} \square$ Yes

32j. Other, please specify:

Thank you! Please give this survey to one of the researchers. 